\title{
IntechOpen
}

\section{Green Practices and Strategies in Supply Chain Management}

\author{
Edited by Syed Abdul Rehman Khan
}





\section{Green Practices and Strategies in Supply Chain Management}

Edited by Syed Abdul Rehman Khan 

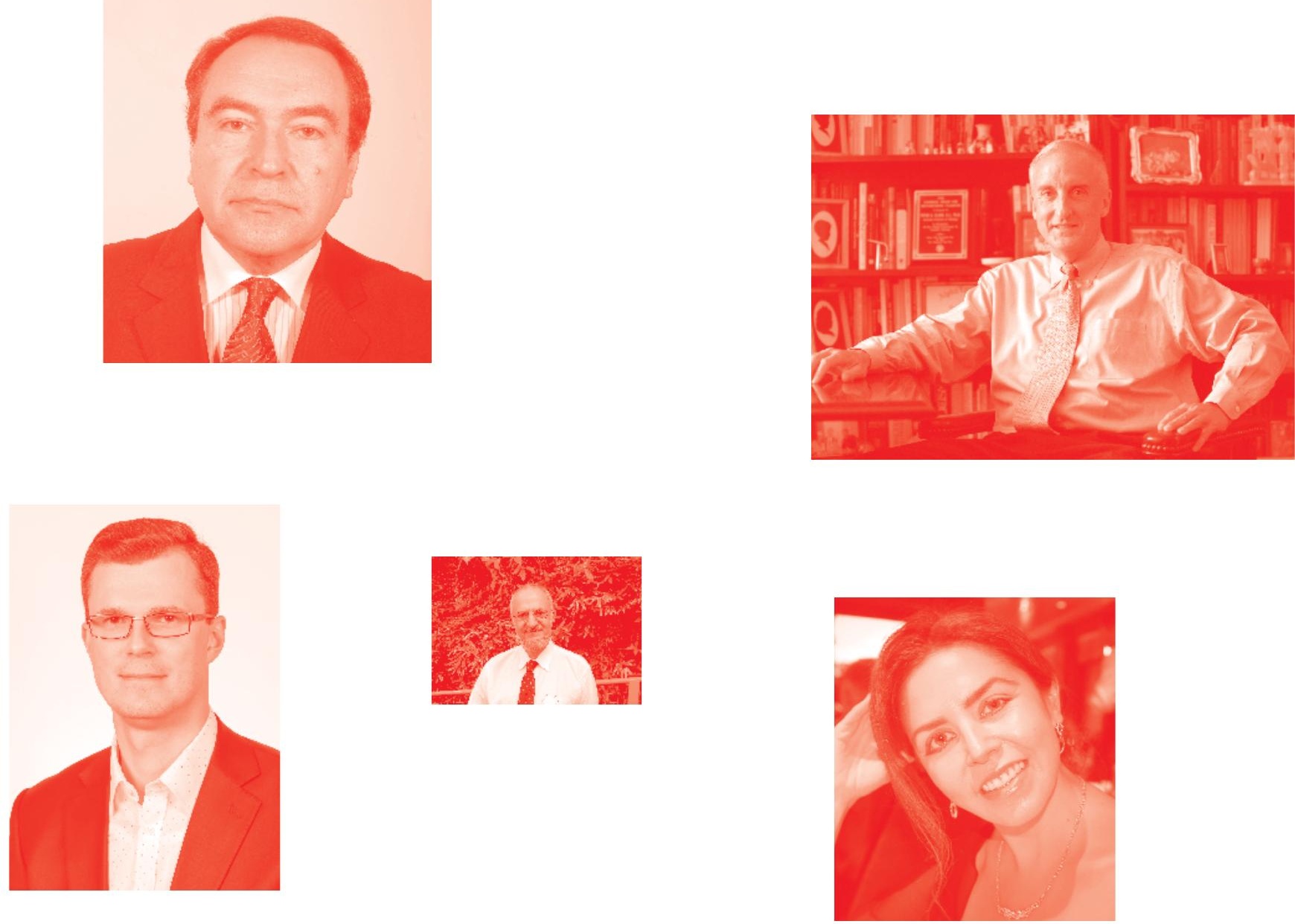

Supporting open minds since 2005
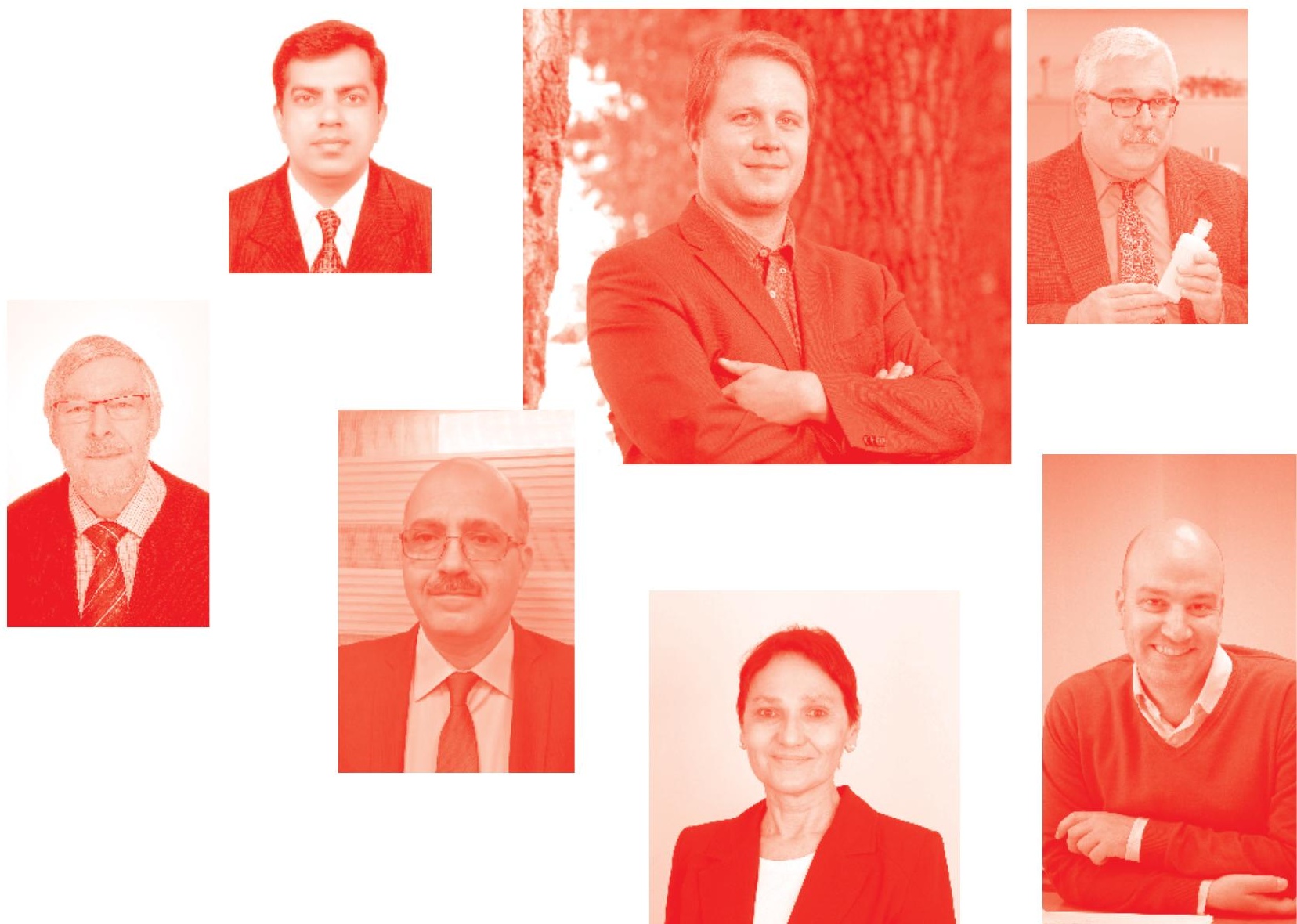
Green Practices and Strategies in Supply Chain Management

http: //dx. doi.org/10.5772/intechopen. 79112

Edited by Syed Abdul Rehman Khan

\section{Contributors}

Kuninori Suzuki, Nobunori Aiura, Syed Abdul Rehman Khan, Amrinder Kaur, Rinku Bhardwaj, Kenneth Mathu

( ) The Editor(s) and the Author(s) 2019

The rights of the editor(s) and the author(s) have been asserted in accordance with the Copyright, Designs and Patents Act 1988. All rights to the book as a whole are reserved by INTECHOPEN LIMITED. The book as a whole (compilation) cannot be reproduced, distributed or used for commercial or non-commercial purposes without INTECHOPEN LIMITED's written permission. Enquiries concerning the use of the book should be directed to INTECHOPEN LIMITED rights and permissions department (permissions@intechopen.com).

Violations are liable to prosecution under the governing Copyright Law .

\section{(cc) BY}

Individual chapters of this publication are distributed under the terms of the Creative Commons Attribution 3. 0 Unported License which permits commercial use, distribution and reproduction of the individual chapters, provided the original author(s) and source publication are appropriately acknowledged. If so indicated, certain images may not be included under the Creative Commons license. In such cases users will need to obtain permission from the license holder to reproduce the material. More details and guidelines concerning content reuse and adaptation can be found at http : //www . intechopen . com/copyright-policy . html .

\section{Notice}

Statements and opinions expressed in the chapters are these of the individual contributors and not necessarily those of the editors or publisher. No responsibility is accepted for the accuracy of information contained in the published chapters. The publisher assumes no responsibility for any damage or injury to persons or property arising out of the use of any materials, instructions, methods or ideas contained in the book.

First published in London, United Kingdom, 2019 by IntechOpen IntechOpen is the global imprint of INTECHOPEN LIMITED, registered in England and Wales, registration number: 11086078 , The Shard, 25th floor, 32 London Bridge Street London, SE19SG - United Kingdom

Printed in Croatia

British Library Cataloguing-in-Publication Data

A catalogue record for this book is available from the British Library

Additional hard and PDF copies can be obtained from orders@intechopen.com

Green Practices and Strategies in Supply Chain Management

Edited by Syed Abdul Rehman Khan

p. cm.

Print ISBN 978-1-83962-183-3

Online ISBN 978-1-83962-184-0

eBook (PDF) ISBN 978-1-83962-185-7 


\section{We are IntechOpen, \\ the world's leading publisher of Open Access books}

\section{Built by scientists, for scientists}

\section{$4,300+$}

Open access books available

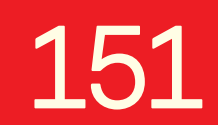

Countries delivered to

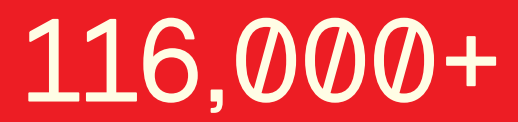

International authors and editors

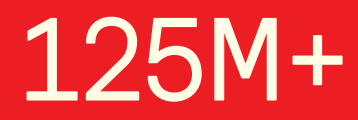

Downloads

Our authors are among the

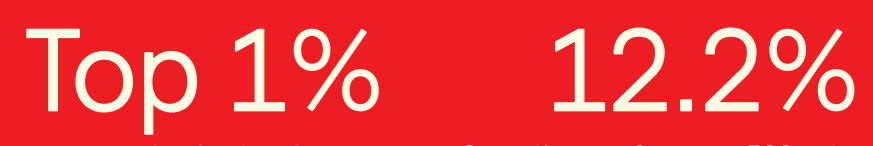

most cited scientists

Contributors from top 500 universities

\section{Interested in publishing with us? \\ Contact book.department@intechopen.com}

Numbers displayed above are based on latest data collected.

For more information visit www.intechopen.com 



\section{Meet the editor}

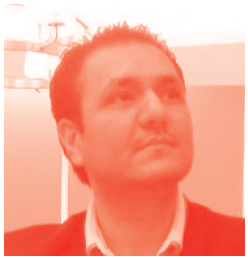

Syed Abdul Rehman Khan is a teacher of supply chain and logistics management. Dr. Khan achieved his Certified Supply Chain Professional certificate from the United States and successfully completed his PhD in China.

Since 2018, Dr. Khan has been affiliated with Tsinghua University as a postdoctoral researcher. He has more than 9 years' core experience of supply chain and logistics at industry and aca-

demic levels. He has attended several international conferences and has also been invited as a keynote speaker to different countries. He has published 70+ scientific research papers in different well-renowned international journals and conferences. $\mathrm{He}$ is a regular contributor to conferences and workshops around the world.

In addition, Dr. Khan has achieved two scientific innovation awards consecutively from the Education Department of Shaanxi Provincial Government, China. Also, Dr. Khan holds memberships in the following well-renowned institutions and supply chain bodies/associations: APCIS, USA; Production and Operations Management Society, India; Council of Supply Chain Management Professionals, USA; Supply Chain Association of Pakistan; and Global Supply Chain Council, China. 



\section{Contents}

$\begin{array}{lll}\text { Preface } & \text { XIII }\end{array}$

Section 1

Introduction $\quad 1$

Chapter 1

Introductory Chapter: Introduction of Green Supply Chain Management

by Syed Abdul Rehman Khan

Section 2

Green Practices and Strategies

Chapter 2

Efficiency Improvement of a Reverse Logistics System

by Kuninori Suzuki and Nobunori Aiura

Chapter 3

Sustainable Supply Chain through Greater Customer Engagement

by Amrinder Kaur and Rinku Bhardwaj

Chapter 4

Green Supply Chain Management: A Precursor to Green Purchasing by Kenneth Mathu 



\section{Preface}

I am very pleased to bring you Green Practices and Strategies in Supply Chain Management. Distinguished researchers from prestigious universities have contributed chapters and cases from real-world events that challenge the brightest minds. Undeniably, the concept of green supply chain management is not very new; however, the focus on green practices and strategies in the supply chain is on the rise from areas such as corporate sector and governmental bodies, protecting the environment, managing scarce resources, employee preservation, and maximizing the value for stakeholders.

This book is concerned with green supply chain management from the vantage point of the triple bottom line: environmental, economic, and social. There are many sustainability decisions that can be made on which we have an incredible impact. Usually, managers have the opportunity to make decisions in five areas of the supply chain: plan, source, make, deliver, and return. The decisions of sustainability are made regarding the design of products, packaging and materials selection, supplier selection, production methods to eliminate waste, what transportation modes to use, and what to do with the products once they reach the end of their lifecycle.

Finally, I would like to thank the contributors/authors of the book for their extraordinary hard work in submitting their valuable and innovative work in the form of chapters. I would also like to thank the Author Service Manager, Ms. Rozmari Marijan for all her assistance. We also extend our thanks to the IntechOpen team for all of their support.

Thank you, 

Section 1

\section{Introduction}





\title{
Introductory Chapter: Introduction of Green Supply Chain Management
}

\author{
Syed Abdul Rehman Khan
}

\section{Introduction}

Since last couple of decades, environmental issues have been increasing and traveling faster than forest fire, country to region, region to world level territory, which is a serious cause of climate change and global warming. In addition, scarcity of natural resources and air and water pollution badly affect the fauna and flora, human life with different diseases they cause definitely, such like ischaemic heart disease, lung cancer, chronic obstruction pulmonary disease, stroke, Dracunculiasis, Cholera, Hepatitis, Typhoid fever, and Norovirus [2]. While, the green supply chain concept occurs to mitigate environmental degradations and control air, water and waste pollution through the adoption of green practices in business operations. Undeniably, the basic ideology behind green concept is to enhanced environmental sustainability, but firms adopt green concept as "kill two enemies with one bullet". Because green supply chain can reduce the environmental pollution and production costs and it also can spur economic growth, create competitive advantage in terms of greater customer satisfaction, positive image and reputation and provide better opportunity to export their products in proenvironmental countries [1]. The definition of green idea is expanding with new innovations and techniques to protect environmental sustainability, which can be recognized by corporate social responsibility, green manufacturing, waste reduction, recycling and remanufacturing sustainable/environmental friendly supply chain, green supply chain, etc.

The term sustainable or green supply chain refers to the idea of integrating sustainable environmental processes into the traditional supply chain. This can include processes such as supplier selection and purchasing material, product design, product manufacturing and assembling, distribution and end-of-life management. Instead of mitigating harmful impact of business and supply chain operations, green supply chain involves value addition and/or value creation through the operations of whole chain. Undeniably, reducing air, water and waste pollution is the main goal of green supply chain, while green operations also enhance firms' performance in terms of less waste manufacturing, reuse and recycling of products, reduction in manufacturing costs, greater efficiency of assets, positive image building, and greater customer satisfaction. Figure 1 displays a green supply chain of child's crib manufacturer as an example.

Green supply chain makes the applications of the key sustainable development strategy outstand. It emphasizes how green practices can be adopted in firms to mitigate the environmental degradations and increase the economic and operational 


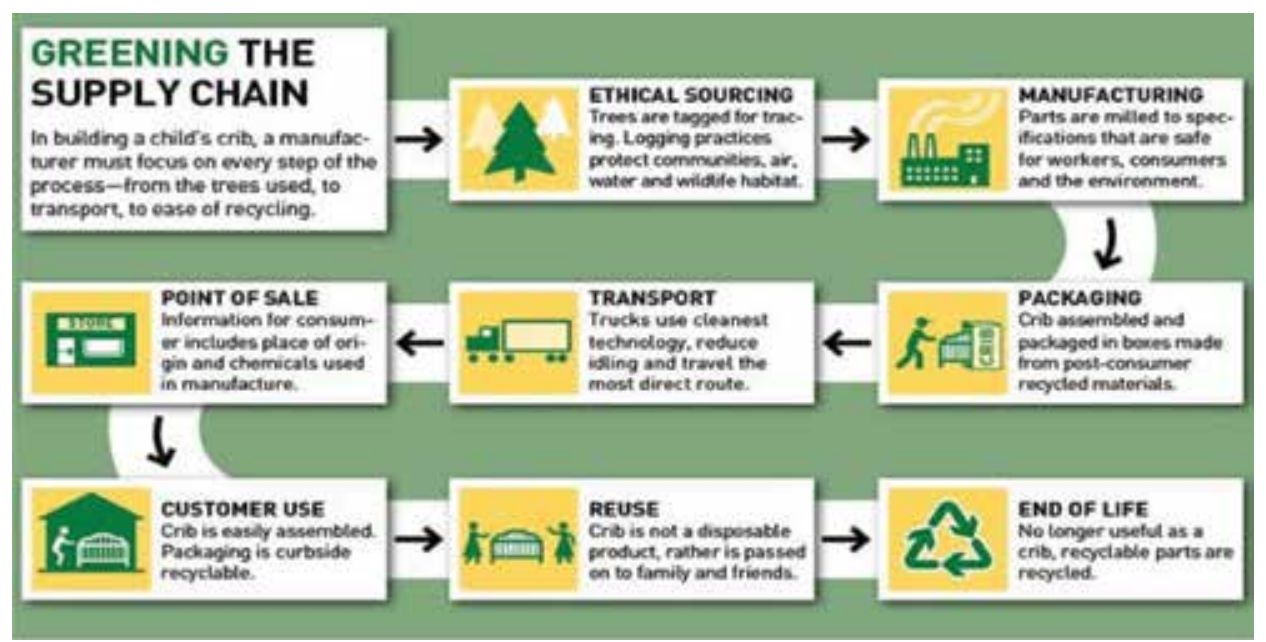

Figure 1.

Green supply chain of child's crib manufacturer.

performance of firms, while Figure 2 illustrates a simple model of green supply chain. Khan et al. [2] have explained the concepts of sustainable and green supply chain management:

Application of environmental management principles to the entire set of activities across the whole customer order cycle, including, design, procurement, manufacturing and assembly, packaging, logistics and distribution [3].

Integrating environmental thinking into supply chain management, including ecological design of products, purchasing green materials and components, reengineering of manufacturing steps towards ecofriendly, reverse logistics management of the product after its useful life [4].

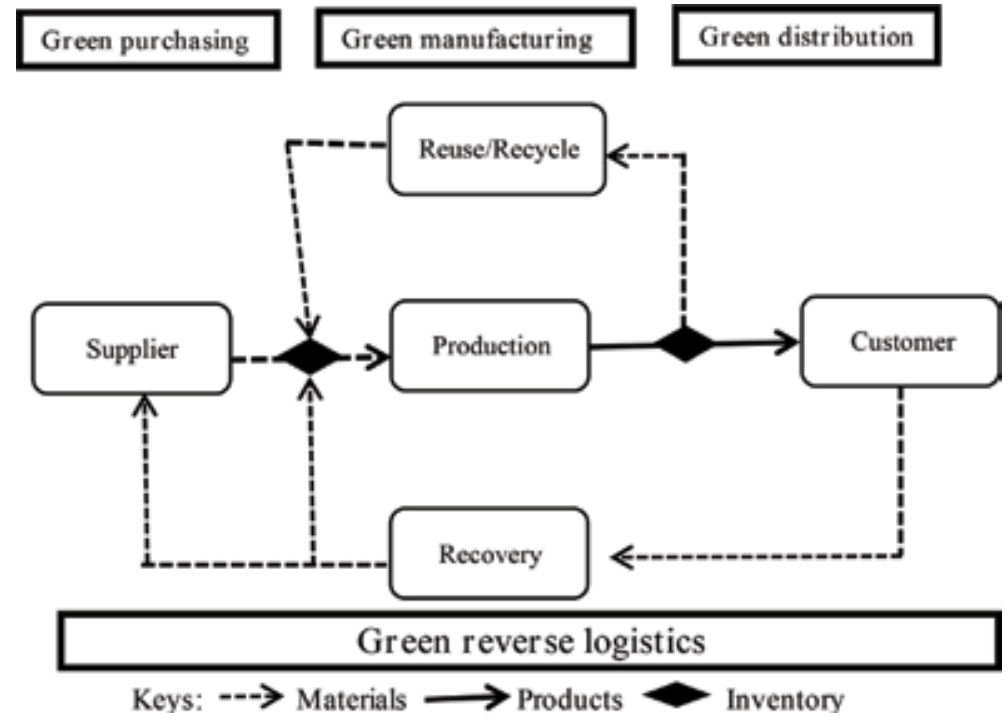

Figure 2.

Simple model of GSCM. 
Introductory Chapter: Introduction of Green Supply Chain Management

DOI: http://dx.doi.org/10.5772/intechopen.81088

Integrating environmental consideration onto firms' supply chain including reverse logistics [5].

Reducing and controlling the harmful impacts of supply chain on the environment [6].

Adoption of ecological design, sourcing green materials and chemicals, and provide green trainings to employees under ethical leadership [7].

Green supply chain are integrating ecofriendly concept into supply chain management to improve environmental sustainability with different green practices including, green purchasing, green distribution and warehousing, green transportation with usage of biofuels, green manufacturing processes and the products' end-of-life management $[2,7]$.

In the World, as the environmental awareness is increasing, firms are facing heavy pressure from different stakeholders including government and customers to mitigate their harmful effect on the environment [8]. Indeed, corporate sector needs to consider integrating their business practices in service and manufacturing industry with sustainability and reducing end-to-end supply chain costs to achieve competitive advantage $[1,9]$. Since last couple of decades, growing impacts of global warming, climate change, waste and air pollution issues have involved increasing world-wide attention of experts to think more ecofriendly and find optimum possible solution towards "Green” [10, 11]. Rath [12] identified GSCM (green supply chain management) plays a part in motivating organizational sustainability. With the environmental concerns rising continuously, GSCM deserves a persistent community concern in developed nations. Further, it has recently woken up the developing nations to the green movement [13].

\section{The role of critical success factors in GSCM}

There is no doubt that green supply chain is a relatively new idea, which is gaining popularity so as to improve environmental performance in the whole chain [5, 14]. We have identified the following six key critical success factors for putting green supply chain management into practice to attain better environmental sustainability

- Ethical leadership/internal management

- Customer management

- Supplier management

- Competitiveness

- Societal

- Regulatory

\subsection{Ethical leadership/internal management}

Internal environment management contains support and encouragement from senior managers. Internal management is a key critical success factor for enterprises 
to adopt green practices. Pressure employees bring about, encouragement and support from environmental-protection motivate senior management. Meanwhile, the perception of environmental risks involved could bring positive change in adoption of green practices $[8,15,16]$.

\subsection{Customer management}

In green supply chains, customers play an important and effective part [13]. Indeed, developing nations' firms are facing heavy pressure to adopt green practices in their business operations of supply chain to meet their customers' demand so that they can be competitive in the market [17]. Cooperation with customers becomes very useful to attain fruitful advantages from green supply chain management $[7,18]$.

\subsection{Supplier management}

Green supply chain practices are unable to be adopted without active participation of customers and suppliers $[19,20]$. Strong collaboration with suppliers enhances incentive systems, boosts the adoption and development of innovative ecofriendly ideas. Technologies, green partnership agreements and openness in implementation of innovative green practices may generate enhancement in operational and environmental performance so as to achieve economic goals of firms [21].

\subsection{Competitiveness}

A number of published researches showed that competence and relevant elements could play a part in green practices implementation in their supply chain [22, 23]. Competitiveness has been perceived as a significant factor to implement green practices rather than organizations' wish to protect environmental sustainability. Implementing green practices in firms' business operations may also be dated back to additional voluntary for competitive factors [8].

\subsection{Social}

A number of researchers found the significance of societal factors for attaining environmental friendly practices objectives [15, 22, 24]. With growing attention of regulatory bodies and awareness of customers on environment, firms have to exchange end-to-end information regarding their supply chain operations' effect on local community and people lives [25]. In addition, NGOs (nongovernment organizations), electronic and social media are more effective in exerting pressure on firms to adopt green practices.

\subsection{Regulatory}

Increasing prominence of environmental concerns has forced regulatory authorities to strict their environmental laws and policies $[8,26]$. Governmental bodies have been farming strict environmental laws to control climate change, global warming and pollution; and firms are required to reduce their supply chain's negative effect on environmental sustainability [27]. Hence, it becomes more and more important for firms in supply chain to have conformity with regulations so as to conducting ecofriendly strategies. 


\section{Green practices in supply chain management}

With numerous green practices adopted, companies in their business and supply chain operations improve their productivity with better environmental growth. While, some well-known green practices are as follows;

\subsection{Green material sourcing}

Green sourcing means sourcing or purchasing materials and components which have such enviable ecofriendly characteristics as reusability, recyclability and nonuse of hazardous/dangerous chemicals [28]. With more and more concerns on environmental protection, procurement professionals have been motivated to reconsider their existing sourcing, purchasing strategy and their impact on environmental sustainability $[29,30]$. The role of ecofriendly purchasing is the involvement of recycling and remanufacturing. Min and Galle [31] further emphasized green sourcing supporting waste reduction enhances recycling and remanufacturing and other activities in supply chain. Carter and Rogers [32] did a research to explore the impact of green sourcing on firms' environmental and financial performance. They concluded that owing to the successful adoption of green purchasing strategy, products' cost is reduced and environmental performance and financial performance of firms is increased with positive reputation obtained in the market. Zailani et al. [33] highlighted that ecofriendly purchasing has positive relationship with firms' operational and environmental performance. Yang et al. [34] green purchasing was categorized into five main facets: design operation management, supply chain management, environmental authentication, ecological, and external environmental management. They confirmed that green purchasing improved to the overall firms' performance [35]. The adoption of green purchasing in supply chain and business operations is a reliable tool in mitigating waste, air and water pollution.

\subsection{Green marketing}

The actions directed to all incorporates and consumers comprise green marketing, a broad range of marketing activities (e.g., planning, production,, process, price, promotion and after-sale service) designed to illustrate the goal of organization to mitigate the harmful effects of their products [36]. Green marketing practice promotes the products with environmental friendly properties [8,37]. It contains the activities that can satisfy human desires of minimum negative effects on the environmental beauty. In addition, green marketing enhances firms' competitiveness and financial and environmental performance with positive corporate reputation and image $[35,38]$.

\subsection{Green management}

Green management practices (GMP) provide a firm with supplementary sources of information that can enhance their business and environmental objectives [39]. Adoption of green management practices help with improved firm image, increased efficiency, environmental compliance improvement, cost savings, achievement of societal commitment and reduction of carbon emissions etc. [40, 41].

\subsection{Green distribution and warehousing}

Green distribution and warehousing can reduce the waste and play an important role in energy reduction and value addition of green products in warehousing 
significantly improve overall performance of organization with better corporate image [7]. Green distribution helps enterprises to obtain superior financial and environmental performance $[42,43]$.

\subsection{Green manufacturing}

Green manufacturing practices are to implement socially and environmentally accountable practices to mitigate harmful effects of manufacturing and increased profitability of firms $[8,29]$. Green practices in production improve efficiency of processes [33]. This practice involves the application of the green resources, which may lead towards competitive advantage through reduction in products' cost and improvement in products' quality. Lean and green manufacturing industry both are working for eliminating waste and improving the efficiency of manufacturing processes [43]. Baines et al. [42] highlighted the benefits of green manufacturing: green practices in production processes mitigate the bad effects of manufacturing processes on environmental sustainability, while green manufacturing improve operational, environmental and financial performance of firms.

\subsection{Ecological design}

Luthra et al. [8] highlighted that $80 \%$ impacts on environment from product and process related could be controlled with the adoption of ecological design in supply chain management. Ecological design incorporates many ideas such like using cleaner technology processes, green raw material and components $[28,44]$. Green design of products reduces ecological impacts of products during their life $[8,45]$. In addition, green design of products also supports reusing, recycling and remanufacturing of products, which not only helps firms to improve their environmental performance but also provide opportunity to reduce their costs [1].

\subsection{Green transportation and reverse logistics}

Green transportation and reverser logistics practices provide opportunity to organizations, to improve their image and reduce their costs [46]. Logistics overheads can be saved through promoting transportation system's efficiency and enhancement of customer association also can be obtained to create more profitability [8]. The logistics activities integrated with rehabilitation comprise the practice of reverse logistics (reusing, recycling, and remanufacturing), which can produce the products that can be used again for customers [29]. Green logistics practice helps firms to reduce their environmental impacts with improved quality and cost reductions [47].

\subsection{Renewable energy and biofuels}

Undeniably, global logistical and supply chain operations mainly depend on energy as well as fossil fuel, which are the main cause of climate change, global warming and pollution with greater carbon and greenhouse gas emissions [46]. Renewable energy and biofuels are required in supply chain operations so as to obtain sustainable environmental and economic growth [48]. Anable et al. [49] highlight that logistics related activities consume greater energy to accomplish their task. Renewable energy and biofuels improve economic performance of firms and also reduce carbon emissions. In addition, fossil fuel is more expensive than biofuels and green energy sources [50]. The strict governmental policies together with customer awareness build pressure on corporate sector to use biofuels and 
environmental friendly energy in their supply chain operations. The bioenergy mitigates the carbon emissions and also improves profitability of enterprises with better image and reputation building [7, 46].

The cost minimization is considered as the most important factor for firms to implement green practices in their supply chain operations. The implementation of green supply chain initiatives would help to cut down the costs of packaging, components and materials due to use of reused, recycled and remanufactured products. Khan et al. [2, 46] highlighted that green practices provide opportunity to capture new markets and export to pro-environmental countries, while polluted firms are unable to export their products in pro-environmental countries such as USA, Germany, UK and Poland. Undeniably, green supply chain management practices have been a tool for firms to decrease their products' cost, enhance profitability and increase market share [51]. On the other hand, to improve social performance, firms also adopt green practices in their business activities. Social performance indicates improvement of people's quality life standard without compromising on environmental beauty. In addition, social performance includes the enhancement of firm image and the improvement of environmental sustainability, as well as reduction in environmental risks [29].

By adopting GSCM practices, firms may enhance their operational performance through improving products quality and improving delivery service [15]. Green supply chain management initiatives also help organizations to improve their environmental performance such as reduction in carbon emissions, elimination of waste from endto-end supply chain, effective and strong collaboration with suppliers would decrease their communication costs and easily promote reuse, recycling and remanufacturing [52]. Environment management system (EMS) integrated into firms' manufacturing strategy will assist the firms to enhance its ecological performance [53].

\section{Author details}

Syed Abdul Rehman Khan

School of Economics and Management, Tsinghua University, Beijing, China

*Address all correspondence to: sarehman_cscp@yahoo.com

IntechOpen

(C) 2018 The Author(s). Licensee IntechOpen. This chapter is distributed under the terms of the Creative Commons Attribution License (http://creativecommons.org/licenses/ by/3.0), which permits unrestricted use, distribution, and reproduction in any medium, provided the original work is properly cited. (cc) BY 


\section{References}

[1] Khan SAR, Dong Q. Impact of green supply chain management practices on firms' performance: An empirical study from the perspective of Pakistan. Environmental Science and Pollution Research. 2017;24:16829-16844. DOI: 10.1007/s11356-017-9172-5

[2] SAR K, Dong Q, Wei SB, Khalid Z, Yu Z. Environmental logistics performance indicators affecting per capita income and sectoral growth: Evidence from a panel of selected global ranked logistics countries. Environmental Science and Pollution Research. 2017;24(2):15181531. DOI: $10.1007 / \mathrm{s} 11356-016-7916-2$

[3] Handfield R, Walton S, Seegers L, Melnyk S. Green' value chain practices in the furniture industry. Journal of Operations Management. 1997;15(4):293-315

[4] Srivastava S. Green supply-chain management: A state-of-the-art literature review. International Journal of Management Reviews. 2007;9(1):53-80

[5] Sarkis J, Zhu Q, Lai K. An organizational theoretic review of green supply chain management literature. International Journal of Production Economics. 2011;130(1):1-15

[6] Andic E, Yurt O, Baltacioglu T. Green supply chains: Efforts and potential applications for the Turkish market. Resources, Conservation and Recycling. 2012;58:50-68

[7] Khan SAR, Dong QL, Yu Z. Research on the measuring performance of green supply chain management: In the perspective of China. International Journal of Engineering Research in Africa. 2016;27:167-178. DOI: 10.4028/ www.scientific.net/JERA.27.167

[8] Luthra S, Garg D, Haleem A. The impacts of critical success factors for implementing green supply chain management towards sustainability: An empirical investigation of Indian automobile industry. Journal of Cleaner Production. 2016;121:142-158

[9] Gunasekaran A, Spalanzani A. Sustainability of manufacturing and services: Investigations for research and applications. International Journal of Production Economics. 2012;140(1):35-47

[10] Rostamzadeh R, Govindan K, Esmaeili A, Sabaghi M. Application of fuzzy VIKOR for evaluation of green supply chain management practices. Ecological Indicators. 2015;49:188-203

[11] Mangla S, Madaan J, Chan FT. Analysis of flexible decision strategies for sustainability-focused green product recovery system. International Journal of Production Research. 2013;51(11):3428-3442

[12] Rath RC. An impact of green marketing on practices of supply chain management in Asia: Emerging economic opportunities and challenges. International Journal of Supply Chain Management. 2013;2(1):78-86

[13] Kumar A, Jain V, Kumar S. A comprehensive environment friendly approach for supplier selection. Omega. 2014;42(1):109-123

[14] Madaan J, Mangla S. Decision modeling approach for eco-driven flexible green supply chain. In: Systemic Flexibility and Business Agility. India: Springer; 2015. pp. 343-364

[15] Yusuf YY, Gunasekaran A, Musa A, EI-Berishy NM, Abubakar T, Ambursa HM. The UK oil and gas supply chains: An empirical analysis of adoption of sustainable measures and performance outcomes. International 
Journal of Production Economics. 2013;146(2):501-514

[16] Holt D, Ghobadian A. An empirical study of green supply chain management practices amongst UK manufacturers. Journal of Manufacturing Technology Management. 2009;20(7):933-956

[17] Omkareshwar M. Green marketing initiatives by corporate world: A study. Advances in Management. 2013;6(3):20-26

[18] Zhu Q, Sarkis J, Lai KH. Green supply chain management: Pressures, practices and performance within the Chinese automobile industry. Journal of Cleaner Production. 2007;15(11):1041-1052

[19] Awasthi A, Kannan G. Green supplier development program selection using NGT and VIKOPR under fuzzy environment. Computers and Industrial Engineering. 2016;91:100-108

[20] Hu AH, Hsu CW. Critical factors for implementing green supply chain management practice: An empirical study of electrical and electronics industries in Taiwan. Management Research and Review. 2010;33(6):586-608

[21] Kaushik A, Kumar S, Luthra S, Haleem A. Technology transfer: Enablers and barriers-A review. International Journal of Technology, Policy and Management. 2014;14(2):133-159

[22] Wang Z, Sarkis J. Investigating the relationship of sustainable supply chain management with corporate financial performance. International Journal of Productivity and Performance Management. 2013;62(8):871-888

[23] Kim J, Rhee J. An empirical study on the impact of critical success factors on the balanced scorecard performance in Korean green supply chain management enterprises. International Journal of Production Research. 2012;50(9):2465-2483

[24] Gunasekaran A, Irani Z, Papadopoulos T. Modelling and analysis of sustainable operations management: Certain investigations for research and applications. The Journal of the Operational Research Society. 2013;65(2):806-823

[25] Shen L, Govindan K, Shankar M. Evaluation of barriers of corporate social responsibility using an analytical hierarchy process under a fuzzy environment-A textile case. Sustainability. 2015;7(3):3493-3514

[26] Jayaram J, Avittathur B. Green supply chains: A perspective from an amerging economy. International Journal of Production Economics. 2015;164:234-244 [Accessed: 16 March 2018]

[27] Mangla SK, Kumar P, Barua MK. Flexible decision approach for analyzing performance of sustainable supply chains under risks/uncertainty. Global Journal of Flexible Systems Management. 2014;15(2):113-130

[28] Eltayeb TK, Zailani S, Ramayah T. Green supply chain initiatives among certified companies in Malaysia and environmental sustainability: Investigating the outcomes. Resources, Conservation and Recycling.

2011;55(5):495-506

[29] Govindan K, Khodaverdi R, Vafadarnikjoo A. Intuitionistic fuzzy based DEMATEL method for developing green practices and performances in a green supply chain. Expert Systems with Applications. 2015;42(20):7207-7220

[30] Handfield R, Walton SV, Sroufe R, Melnyk SA. Applying environmental criteria to supplier assessment: 
A study in the application of the analytical hierarchy process. European Journal of Operational Research. 2002;141(1):70-87

[31] Min H, Galle WP. Green purchasing practices of US firms. International Journal of Operations \& Production Management. 2001;21(9):1222-1238

[32] Carter CR, Rogers DS. A

framework of sustainable supply chain management: Moving toward new theory. International Journal of Physical Distribution and Logistics Management. 2008;38(5):360-387

[33] Zailani S, Govindan K, Iranmanesh M, Shaharudin MR, Chong YS. Green innovation adoption in automotive supply chain: The Malaysian case. Journal of Cleaner Production. 2015;108:1115-1122

[34] Yang CL, Lin SP, Chan YH, Sheu C. Mediated effect of environmental management on manufacturing competitiveness: An empirical study. International Journal of Production Economics. 2010;123(1):210-220

[35] Chen CC, Shih HS, Shyur HJ, Wu KS. A business strategy selection of green supply chain management via an analytic network process. Computers \& Mathematics with Applications. 2012;64(8):2544-2557

[36] Groening C, Sarkis J, Zhu Q. Green marketing consumer-level theory review: A compendium of applied theories and further research directions. Journal of Cleaner Production. 2017:1-19

[37] Polonsky MJ. An introduction to green marketing. Electronic Green Journal. 1994;1(2):1-10

[38] Ko E, Hwang YK, Kim EY. Green marketing functions in building corporate image in the retail setting. Journal of Business Research. 2013;66(10):1709-1715
[39] Pane Haden SS, Oyler JD, Humphreys JH. Historical, practical, and theoretical perspectives on green management: An exploratory analysis. Management Decision. 2009;47(7):1041-1055

[40] Luthra S, Garg D, Haleem A. Empirical analysis of green supply chain management practices in Indian automobile industry. Journal of Institution of Engineers (India): Series C. $2014 ; 95(2): 119-126$

[41] Kang Y, Ryu MH, Kim S. Exploring sustainability management for telecommunications services: A case study of two Korean companies. Journal of World Business. 2010;45(4):415-421

[42] Baines T, Brown S, Benedettini O, Ball $P$. Examining green production and its role within the competitive strategy of manufacturers. Journal of Industrial Engineering and Management. 2012;5(1):53-87

[43] Prajogo D, Chowdhury M, Yeung AC, Cheng TCE. The relationship between supplier management and firm's operational performance: A multi-dimensional perspective. International Journal of Production Economics. 2012;136(1):123-130

[44] Gungor A, Gupta SM. Issues in environmentally conscious manufacturing and product recovery: A survey. Computers and Industrial Engineering. 1999;36(4):811-853

[45] Sarkis J. Evaluating environmentally conscious business practices. European Journal of Operational Research. 1998;107(1):159-174

[46] Khan SAR, Zhang Y, Anees M, Golpîra H, Lahmar A, Dong Q. Green supply chain management, economic growth and environment: A GMM based evidence. Journal of Cleaner Production. 2018;185:588-599 
[47] Mousazadeh M, Torabi SA, Pishvaee MS. Green and reverse logistics management under fuzziness. In: Supply Chain Management under Fuzziness. Heidelberg, Berlin: Springer; 2014. pp. 607-637

[48] Wu C, Barnes D. Partner selection in green supply chains using PSO-A practical approach. Production Planning and Control. 2016;27(13):1041-1061. DOI: 10.1080/09537287.2016.1177233

[49] Anable J, Brand C, Tran M, Eyre $\mathrm{N}$. Modelling transport energy demand: A socio-technical approach. Energy Policy. 2012;41:125-138

[50] Gold S, Seuring S. Supply chain and logistics issues of bio-energy production. Journal of Cleaner Production. 2011;19(1):32-42. DOI: 10.1016/j.jclepro.2010.08.009

[51] De Giovanni P, Vinzi VE. Covariance versus componentbased estimations of performance in green supply chain management. International Journal of Production Economics. 2012;135(2):907-916

[52] Kleindorfer PR, Singhal K, Wassenhove LN. Sustainable operations management. Production and Operations Management. 2005;14(4):482-492

[53] Zhu Q, Sarkis J, Lai KH. Green supply chain management innovation diffusion and its relationship to organizational improvement: An ecological modernization perspective. Journal of Engineering and Technology Management. 2012;29(1):168-185 

Section 2

Green Practices and Strategies 



\title{
Chapter 2
}

\section{Efficiency Improvement of a Reverse Logistics System}

\author{
Kuninori Suzuki and Nobunori Aiura
}

\begin{abstract}
This chapter discusses the efficiency of a series of processes from discarded tire recovery to thermal recycling. A simulation model was developed for improving the efficiency of fuel chip transportation in the Kansai region of Japan, and a simulation analysis was carried out based on actual data. Discarded tires form automobiles are recovered through gas stations, tire shops, etc. The discarded tires are crushed into fuel chips at a recycling factory and are used for thermal recycling. Fuel chips are transported to steelworks, paper mills, etc., and are used as a substitute for coal in boilers at those plants. Fuel chips, made from discarded tires, have about the same fuel efficiency, in terms of calorie performance, as coal. However, it has been directly transported from a recycling factory to steelworks by truck, without any consideration for the environment. Therefore, in this research, this study investigated measures to transport fuel chips efficiently and environmentally, by introducing a modal shift, which combines trucks with marine transport, rather than truck alone. As a result of numerical experiments, it was clarified that adequate results can be obtained if the distance of sea transport is sufficiently far apart for the introduction of a modal shift.
\end{abstract}

Keywords: reverse logistics, collection and transport, recycle, intermediate treatment

\section{Introduction}

The present study focuses on discarded tire-derived fuel chips for thermal recycling and examines the effective introduction of modal-shift transportation.

The present study proposes a delivery system using a "milk-run method through a transshipment depot, into which marine transportation is introduced," instead of using the truck as an effective measure. In the delivery system, discarded tires are treated at an intermediate treatment factory and turned into fuel chips. The fuel chips are then transported and distributed to cement factories and steel and paper mills as valuable materials.

Materials are recycled in such a way that used goods are collected and transported to an intermediate treatment factory, and the used goods are treated to create new products.

Recycled materials used for thermal recycling, such as fuel chips, are not transported and distributed to end users through delivery centers, which handle recycled materials, but in many cases are directly transported and distributed to the warehouses of end users' factories from the warehouses of intermediate treatment factories. 
To review the current system of transporting discarded tire-derived fuel chips, the present study examined the logistics and product features of the fuel chips, simulated the arrangement of transportation complexes for the fuel chips in order to optimize the transportation efficiency, and calculated the driving situation of trucks and the transportation cost of the fuel chips.

\section{Definition of discarded tires and its basic flow}

Concerning the definition of discarded tires, Japan Automobile Tire Manufacturers Association (JATMA) decided to unify the names of used tires into "discarded tires."

Fuel chips derived from discarded tires recycled after intermediate treatment are valuable; therefore, they are transported rather than collected and transported. This chapter will analyze and consider the flow as reverse logistics, which is a series of steps from the collection of discarded tires to the delivery of recycled fuel chips.

Discarded tires collected and transported by the collection network are recycled into discarded tire-derived thermal recycling fuel chips, which combine licenses for both collection and transportation businesses and intermediate processing businesses. After recycling, the fuel chips stored in the warehouse of the intermediate processing factory are shipped according to the orders received from paper mills, steelworks, cement factories, and the like.

Since fuel chips are transported as valuable material in principle, the licenses for transportation businesses are required, but they are not required for collection and transportation projects. However, the fuel chips are not always valuable. Whether they are valuable or not depends on the market.

The Ministry of the Environment in Japan has issued a notice that "the delivery side will bear the shipping costs, and, if the transportation costs exceed the sale price, it will be considered waste."

In the case of reverse payment, it will be treated as waste and transported. Therefore, in view of the possibility that it becomes waste due to market demand, it is desirable that a business owner, who has licenses for both collection and transportation businesses, work with the transportation industry to haul the fuel chips.

Also, if industrial waste is discharged from the supplier and it becomes a return shipment, it is possible to reduce transportation and transportation costs. In other words, delivery from discarded tires to intermediate processing and delivery to discarded tire-derived fuel chips that are recycled and produced can correspond to thermal recycling.

Trucks transport fuel chips for short distances, but, for long distances, a modal shift will be introduced combining marine transportation with truck transportation.

In theory, it is possible to combine sea transportation, but currently it is not done. In many cases, fuel chips are delivered by truck from a nearby waste disposer. The risk of illegal dumping increases when the area is broadened as described above and when the processing company is small in scale. It is difficult to develop large lots in many cases.

However, considering the efficiency of reverse logistics for discarded tires, it is necessary to expand the area of fuel chip transportation as well as widen the collection and transportation networks. Although the amount of waste tires generated is larger in metropolitan areas, the location of paper mills, ironworks, cement factories, and the like will be industrial parks in the suburbs of local cities. 


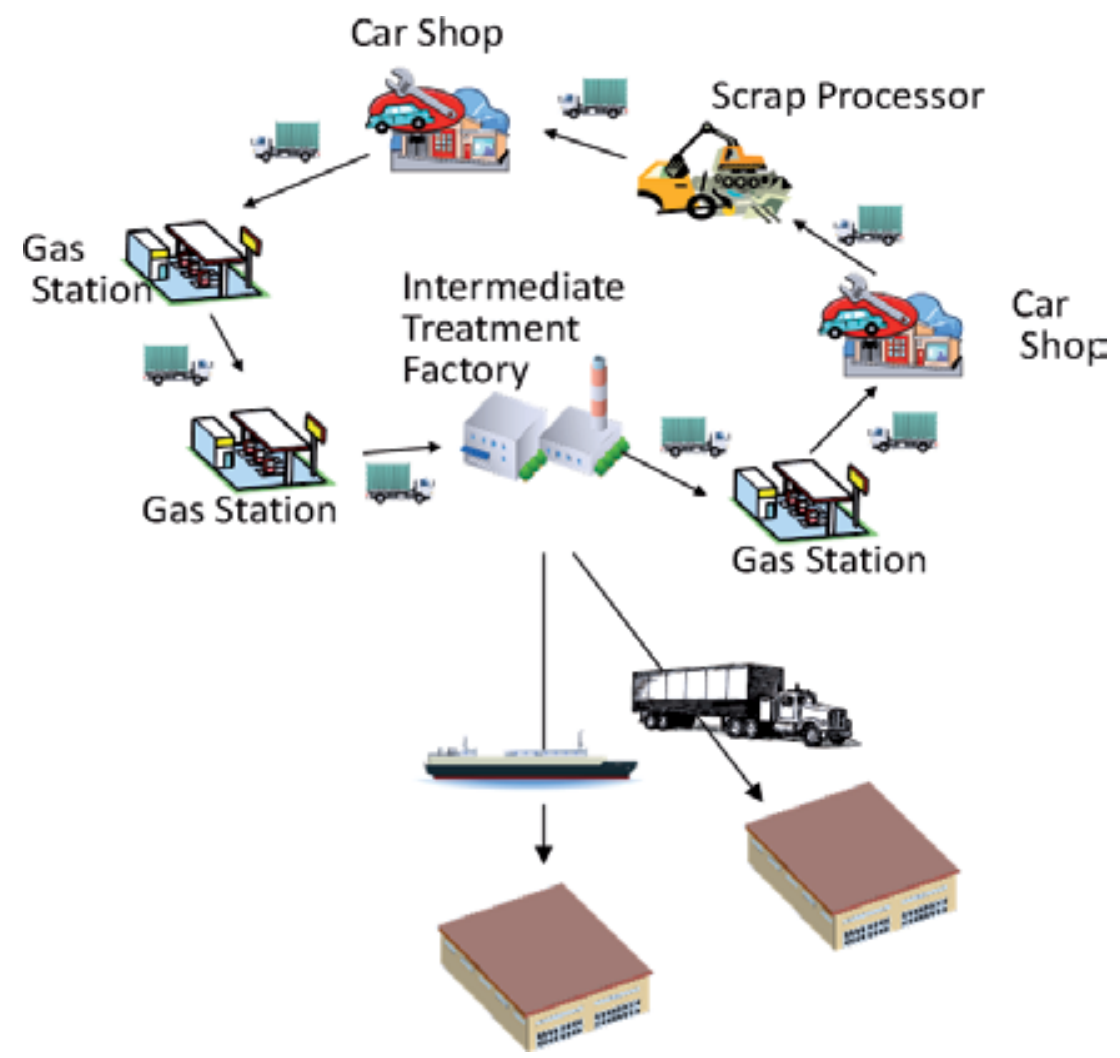

Figure 1.

Material flow of discarded tires.

However, such a local waste tire recovery network alone will not generate the necessary supply of fuel chips. Also, in large metropolitan areas, the number of discarded tires is large, but the number of factories using them is small.

Therefore, if the delivery areas are limited, the destinations for fuel chips that have been recycled will be insufficient. Thus, by increasing the destinations for fuel chips widely, it is possible to effectively supply surplus fuel chips in large cities to regional cities.

However, in order to efficiently supply discarded tires generated in metropolitan areas to rural areas, it will be necessary to construct a system that establishes new transportation depots at local bases to circulate and optimize the route.

As shown in Figure 1 rather than directly transporting large quantities of trucks from the intermediate processing plant in a metropolitan area to a local paper mill, etc., the introduction of a modal shift can carry large lots to local sea ports.

Regarding depots, a system should be established in which a plurality of factories in the area is visited by the milk run system. The newly established depot will have the function of storing exports and acts as a base for temporarily storing fuel chips transported over a long distance from metropolitan areas and the like.

\section{Fuel delivery system: case study}

The fuel chips are packed and transferred to the specific warehouse, where they are stored until shipment by truck [1]. However, Company A can ship big lots, such 
as $1000 \mathrm{t}$, by sea transportation to its specialized customers, which include large paper factories and steel mills that are located further away.

Recycled fuel chips are purchased by companies such as steel mills. Therefore, the supply system needs of those types of companies are different from needs of companies that collect and transport waste tires. For companies such as steel mills, general cargo carriers typically deal with the shipment of materials.

How the waste is determined depends on the market price. In the case of fuel chip recycling, some of the waste materials produced will be assigned a market price that is not valuable. Additionally, potential waste treatment affects the values even if the transportation cost is changed.

Therefore, the treatment or handling of these products is slightly different from the treatment and handling of genuine products, which is why the transportation of the fuel chip is often included in the framework of reverse logistics. Recycled fuel chips are produced by a simple process that cuts the size stipulated by the tire circle cutting machine.

\section{Building a simulation model}

This issue can be explained as a simple multi-stage location model, which consists of production facilities and Transfer Centers, markets.

In Figure 2, the locations of the Transfer Centers and handling products at each Transfer Center are determined to minimize the total cost. This multi-stage location model is comprised of basic operating cost and transportation cost. The site integration is also included in the determination of the location of the Transfer Centers.

In Figure 2, as for the item (1 through i), which are produced in Plant (1 through k), the item (1) and item (2) in the Logistics Site (1), and the item (i-1) and item (i) in the Logistics Site (2) are treated; these items are distributed from both Logistics Sites to Market (1 through 3). All items handled in the Logistics Site m are being supplied to the market (n-1) and market $(n)$. Furthermore, Logistics Site ( $m-1)$ is not located because no handling of the items is required.

Figure 2 shows an example of the supply to the market in which delivery is being made only through the Logistics Sites. However, in this study, it is also possible that items could be sent directly to the customer from the intermediate treatment factory.

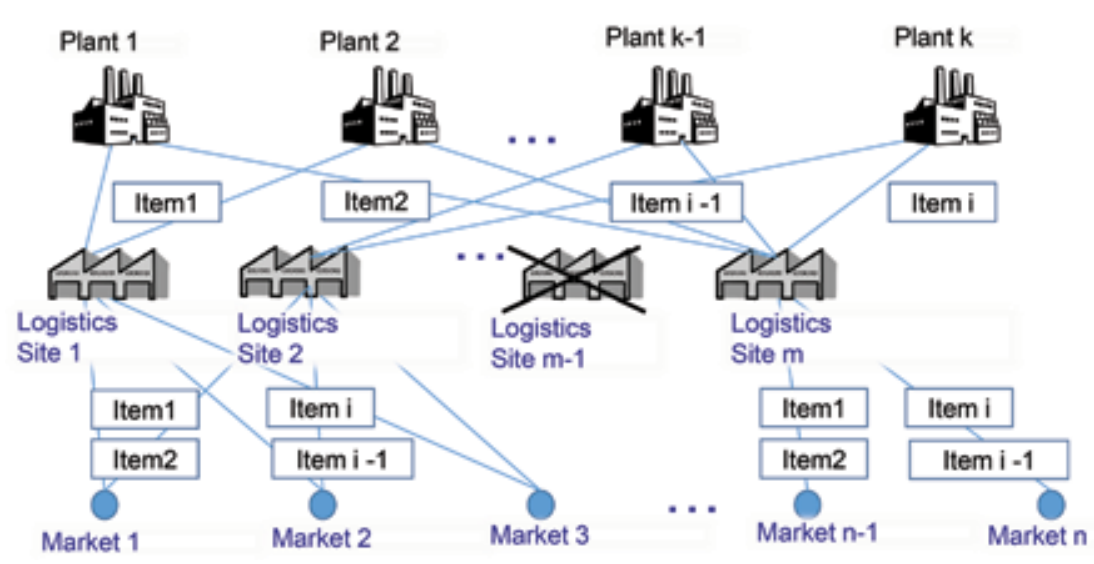

Figure 2.

Example of multi-stage location [2]. 
The similar model has been used for a forward logistics system, but as for the reverse logistics network simulation, this simple multi-stage location model has not been regarded as the effective one.

\section{Data for simulation}

To simulate the arrangement of transportation complexes for discarded tirederived fuel chips, the present study used the actual data of Company A, a wastedisposal operator located in Chigasaki-shi, Kanagawa Prefecture.

Company A collects discarded tires from gas stations, auto repair shops, and tire dealers. In the company's intermediate treatment factory, a recycling process is performed for the collected discarded tires to be turned into fuel chips used in the boilers of cement factories and steel and paper mills.

The fuel chips are then regularly delivered to customers' factories. Before performing the simulation, actual data and estimated values were obtained from factories of the company's present and potential customers by conducting an inperson interview survey. The latitude and longitude of a factory to which fuel chips were assumed to be delivered in the simulation were derived from the address of the factory.

The site for a transshipment depot was set in each delivery area, and an area for transportation and distribution was also set based on the results obtained by performing a hearing survey for the company. Table 1 shows the conditions examined for the simulation of the delivery system based on the actual data.

Regarding potential customers, fuel chips are assumed to be used in many production facilities, which possess boilers, such as food-processing plants, in addition to cement factories and steel and paper mills.

Since the number of discarded tires collected in a local area is limited, it is important to transport and distribute discarded tire-derived fuel chips from the metropolitan area in which a large number of discarded tires can be collected to Tohoku, West Japan, and Kyushu areas in order to satisfy the supply-demand balance.

In the future, a system may be constructed in which discarded tires are imported from foreign countries, including China, and a recycling process is performed to turn the imported discarded tires into fuel chips at intermediate treatment factories in Japan. The fuel chips would then be delivered to each area in Japan.

\begin{tabular}{ll}
\hline Item & Contents \\
\hline Delivery point & West Japan:15 factories(customers) \\
\hline Candidate Sea Port & West Japan: Mizushima, Hiroshima, Kobe, Osaka North \\
\hline Delivery lot & $5-55$ t/week \\
\hline Frequency & $1-2$ times/week \\
\hline Transport mode & 20 t-truck, 1000 t-ship \\
\hline Vehicle & Nonlimited \\
\hline Standard working hour & 8 hour/day \\
\hline Period & 4 weeks \\
\hline
\end{tabular}

Table 1.

Delivery system conditions. 
Company A is a typical collection and transport company, which can enlarge its collection area. Therefore, the data can be used as in a general and typical case for reverse logistics simulation.

To calculate the total transportation cost of discarded tire-derived fuel chips, direct delivery to customers' factories by truck and a combination of marine and land transportations using ship and truck were examined. The location of the port in which a transshipment depot was to be set was examined.

Each candidate sea port can be accepted a 1000 t-bulker-ship, 1-2 times a week, which is dealt with a crane material handling.

\section{Increase in transportation efficiency}

Fuel chips are primarily delivered from company A (the head office and intermediate treatment factory are located in Chigasaki-shi, Kanagawa Prefecture) to factories in each area by truck.

This is because a reverse logistics network for fuel chips was not constructed on the assumption that the delivery area would be expanded; it was constructed from the perspective that even if fuel chips were delivered by truck, no problem would arise when the transport volume was small.

However, when the reverse logistics network is expanded, fuel chips treated in the company A's intermediate treatment factory in Kanagawa Prefecture are delivered to factories in the Kanto area and to all parts of Japan.

Previously, fuel chips produced from discarded tires in an intermediate treatment factory were mainly delivered to cement factories and steel and paper mills in each area. If fuel chips are delivered from the Kanto area, in which a large number of tires are discarded, fuel chips can be consistently supplied.

However, if large amounts of fuel chips are transported by truck as one lot, various problems, such as traffic congestion, noise problems, and environmental deterioration, will arise in prefectures through which the truck passes.

Therefore, a combination of trucking and shipping is a useful option because the truck is suitable for door-to-door delivery of small amounts of fuel chips and the ship is suitable for transporting and distributing large amounts of fuel chips.

Moreover, the environmental load of a ship is small. In other words, fuel chips are transported from the company A's intermediate treatment factory in Kanagawa Prefecture to the Port of Kawasaki by truck, and then large amounts of fuel chips are transported as one lot from the Port of Kawasaki to each area by ship.

A transshipment depot is set in the main port of each area, and fuel chips are delivered from the transshipment depot to destinations one after another by truck (the milk-run method).

\section{Delivery to the Kansai area in Japan}

At present, direct delivery of fuel chips by truck as one lot from the company A's intermediate treatment factory in Chigasaki-shi, Kanagawa Prefecture to West Japan (Shiga, Kyoto, Osaka, Hyogo, Okayama, Hiroshima, Tottori, and Yamaguchi Prefectures) is not performed. However, there are many potential customers in that area.

Large amounts of fuel chips are transported as one lot from the Port of Kawasaki to West Japan by ship. In the present study, Company A established its own transshipment depot in West Japan and delivers fuel chips from the depot to 15 paper mills one after another (the milk-run method). It was assumed to establish its 
own transshipment depots in Osaka North Port, the Port of Kobe, the Port of Mizushima, and Hiroshima Port.

Regarding the weekly cost for direct delivery of fuel chips by truck from the company A's intermediate treatment factory to West Japan, the simulation results revealed that the variable cost, including the fuel cost, was 275,194 yen; the labor cost for truck drivers was 359,000 yen; and the fixed cost, including the insurance cost and vehicle expenses, was 1,400,000 yen, that is, the total transportation cost per week was 2,034,194 yen. The travel distance was 13,209.68 km. The transit time was $165.12 \mathrm{~h}$. The loading was $225 \mathrm{t}$. The number of trucks used for the transportation was 14 .

In the case where Hiroshima Port as in Figure 3 was used for the transshipment depot, the variable cost was 133,752 yen, the labor cost for truck drivers was 115,200 yen, and the fixed cost was 459,000 yen, that is, the total transportation cost per week was 707,952 yen. The travel distance was $6420.28 \mathrm{~km}$. The transit time was $80.25 \mathrm{~h}$. The loading was $225 \mathrm{t}$.

The number of trucks used for the transportation was nine. The total cost of transporting fuel chips was 10,643,328 yen. Thus, the total transportation cost per week was much lower when Hiroshima Port was used for the transshipment depot than when fuel chips were directly delivered from company A's intermediate treatment factory to West Japan. However, after setting the transshipment depot, the running costs for the depot were required.

Consequently, the total cost of transporting fuel chips was higher in the case, where Hiroshima Port was used for the transshipment depot than in the case, where fuel chips were directly delivered.

The variable, labor, and fixed costs were revealed to be significantly lower in the case, where the Port of Mizushima was used than in the case where Hiroshima Port was used for the transshipment depot. The total transportation cost per week was 707,952 yen when using Hiroshima Port and that was 402,354 yen when using the Port of Mizushima.

Loading at Hiroshima Port as in Figure 4 was the same as at the Port of Mizushima (225 t). The travel distance was $6420 \mathrm{~km}$ when using Hiroshima Port and $4001 \mathrm{~km}$ when using the Port of Mizushima. The transit time was $80 \mathrm{~h}$ when using Hiroshima Port and $50 \mathrm{~h}$ when using the Port of Mizushima.

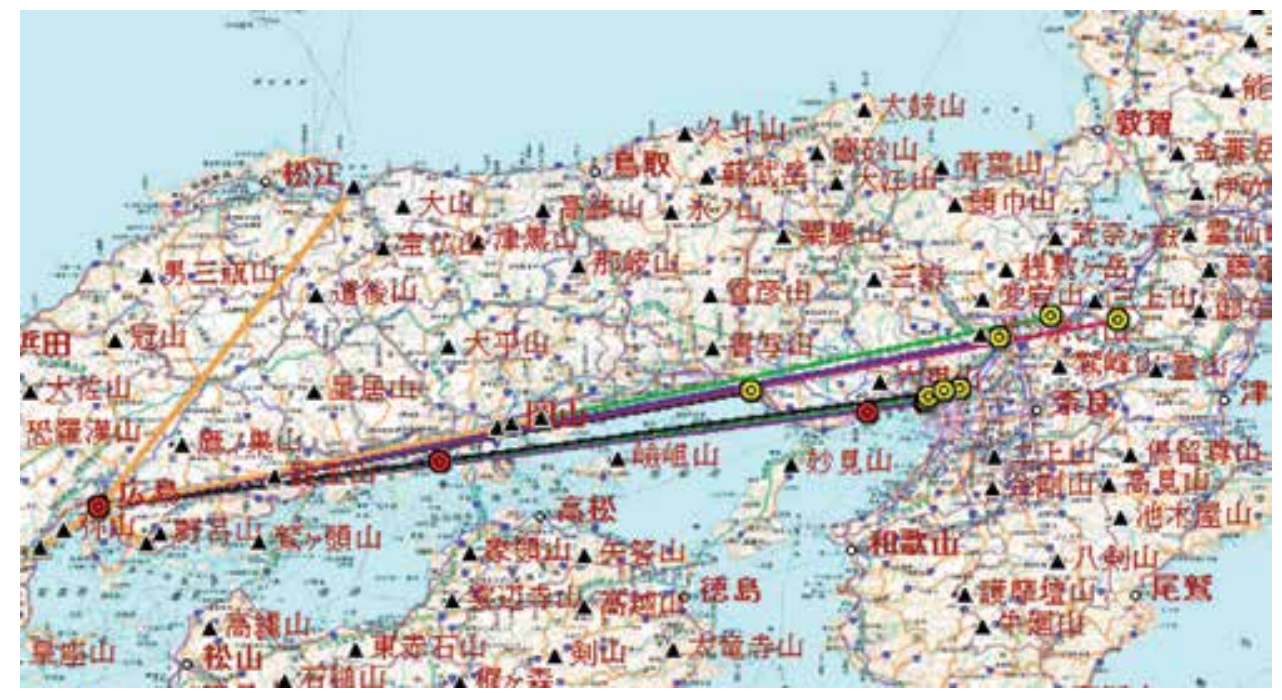

Figure 3.

Use of Hiroshima Sea Port. Delivery point: Shiga, Kyoto, Osaka, Hyogo, Okayama, Tottori, Hiroshima, Yamaguchi. 


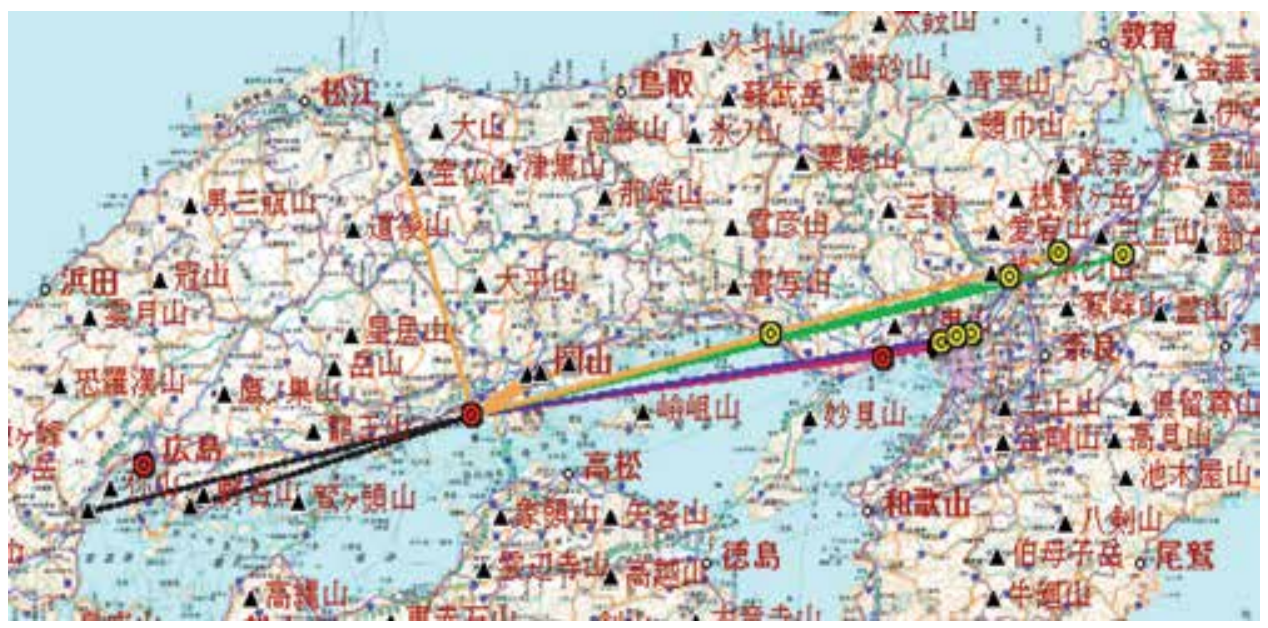

Figure 4.

Use of Mizushima Sea Port. Delivery point: Shiga, Kyoto, Osaka, Hyogo, Okayama, Tottori, Hiroshima, Yamaguchi.

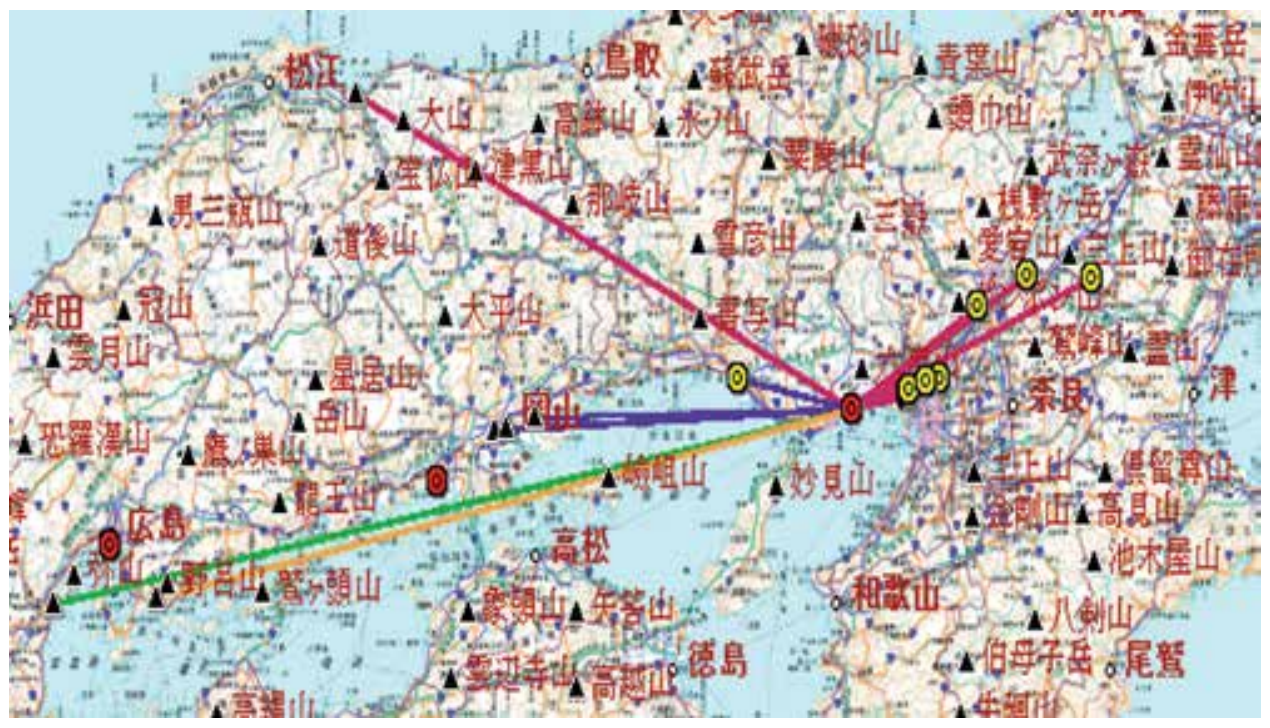

Figure 5.

Use of Osaka North Sea Port. Delivery point: Shiga, Kyoto, Osaka, Hyogo, Okayama, Tottori, Hiroshima, Yamaguchi.

The number of trucks used for the transportation was nine when using Hiroshima Port and five when using the Port of Mizushima. Thus, the Port of Mizushima was superior to Hiroshima Port in terms of the transportation and distribution of fuel chips. However, the total cost of transporting fuel chips per month was slightly higher when the Port of Mizushima was used for the transshipment depot than when fuel chips were directly delivered.

When Osaka North Port as in Figure 5 was used for the transshipment depot, the variable cost was 59,582 yen, the labor cost for truck drivers was 51,200 yen, and the fixed cost was 204,000 yen, that is, the total transportation cost per week was 314,782 yen. The loading was assumed to be $225 \mathrm{t}$. The travel distance was $2860 \mathrm{~km}$.

The transit time was $35 \mathrm{~h}$. The number of trucks used for the transportation was four. Therefore, the total transportation cost per week, the travel distance, the 


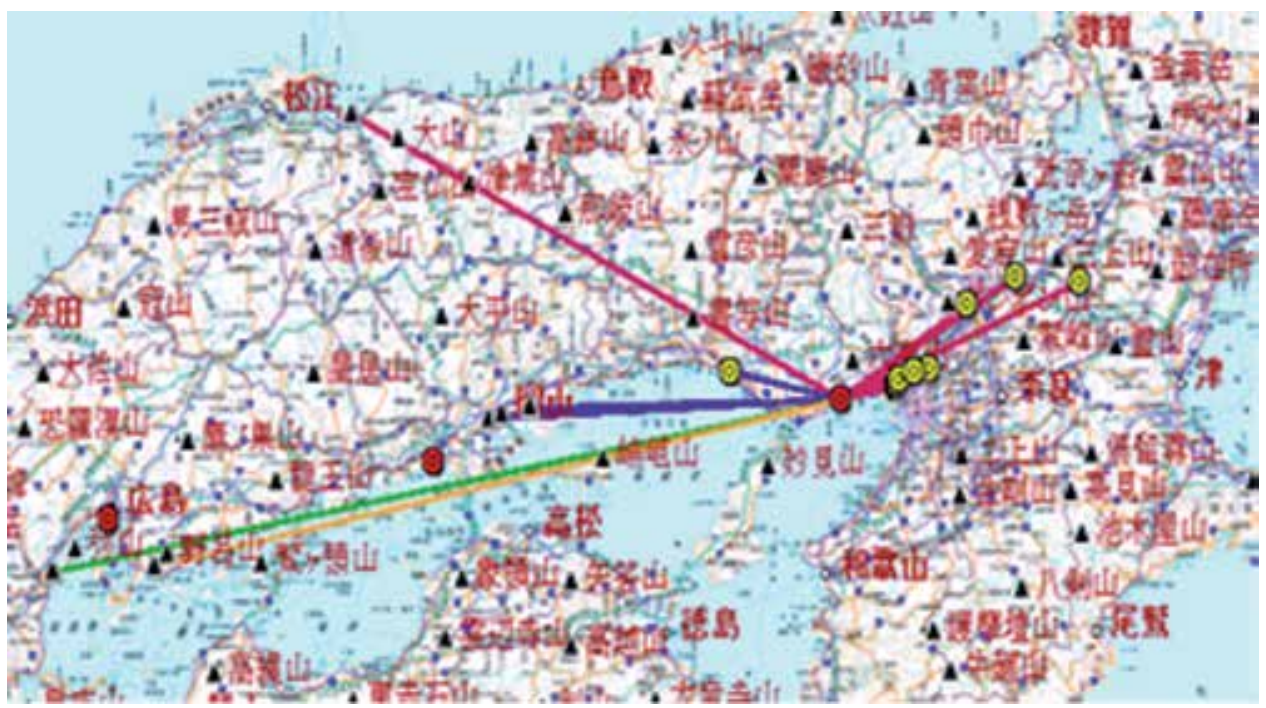

Figure 6.

Use of Kobe Sea Port. Delivery point: Shiga, Kyoto, Osaka, Hyogo, Okayama, Tottori, Hiroshima, Yamaguchi.

\begin{tabular}{|c|c|c|c|c|c|}
\hline site & \begin{tabular}{|l|l} 
distance $(\mathrm{km})$ & distance $(\mathrm{km})$ \\
\end{tabular} & & shipping lot (t) & number of trucks & total cost (yen) \\
\hline truck direct delivery & 13209.68 & 165.12 & 225 & 14 & 8136776 \\
\hline Hiroshima & 6420.28 & 80.25 & 225 & 9 & 8519472 \\
\hline Mizushima & 4001 & 50 & 225 & 5 & 8213874 \\
\hline Osaka North & 2860 & 35 & 225 & 4 & 8837224 \\
\hline Kobe & 2860 & 35 & 225 & 4 & 8140552 \\
\hline
\end{tabular}

Table 2.

Numerical result.

transit time, and the number of trucks were lower when using Osaka North Port than the Port of Mizushima.

However, the running costs for the transshipment depot were 7,578,096 yen, and the total cost of transporting fuel chips was 8,837,224 yen when using Osaka North Port, which was higher than using the Port of Mizushima (8,565,312 yen).

Although Osaka North Port was superior to the Port of Mizushima in terms of the total transportation cost per week, the travel distance, the transit time, and the number of trucks, the total cost of transporting fuel chips was higher when using Osaka North Port than for the Port of Mizushima because the land rent for the transshipment depot was higher in Osaka North Port than in the Port of Mizushima.

Consequently, the total cost of transporting fuel chips was higher when Osaka North Port was used for the transshipment depot than when fuel chips were directly delivered by truck from Chigasaki-shi, Kanagawa prefecture.

As shown in Figure 6 and Table 2, the total transportation cost per week, the travel distance, the transit time, and the number of trucks when using the Port of Kobe were the same as those when using Osaka North Port, that is, the total transportation cost per week was 314,782 yen. The travel distance was $2860 \mathrm{~km}$. The transit time was $35 \mathrm{~h}$.

The number of trucks used for the transportation was four. However, the running costs for the transshipment depot were lower when using the Port of Kobe.

Consequently, the total cost of transporting fuel chips was lower when the Port of Kobe was used for the transshipment depot than when the Port of 
Mizushima was used for the transshipment depot (8,565,312 yen) and when fuel chips were directly delivered by truck from Chigasaki-shi, Kanagawa prefecture $(8,136,776$ yen).

The results obtained by performing the simulation can be summarized as follows:

1. The total transportation cost per week, the travel distance, the transit time, and the number of trucks when using the Port of Kobe were the same as those when using Osaka North Port.

2. The Port of Kobe and Osaka North Port were superior to the Port of Mizushima and Hiroshima Port in terms of the total transportation cost per week, the travel distance, the transit time, and the number of trucks.

3. When the running costs for the transshipment depot were taken into account, the total cost of transporting fuel chips was higher when using Osaka North Port than when using the Port of Mizushima because the land rent for the transshipment depot was higher.

4. The total cost of transporting fuel chips was lower when using the Port of Kobe than when using the Port of Mizushima because the land rent for the transshipment depot was lower.

5. The total cost of transporting fuel chips was lower when a transshipment depot was set in the Port of Kobe than when fuel chips were directly delivered by truck from the intermediate treatment factory in Kanagawa prefecture.

\section{Future tasks and direction}

The results obtained by performing the simulation revealed that the transportation efficiency of fuel chips from the Port of Kawasaki to the Kansai area using the milk-run method was higher when a transshipment depot was set in Kobe Port than when a transshipment depot was set in the Port of Mizushima, Hiroshima Port, or Osaka North Port.

The model used in the present study was considered to be useful for examining modal-shift transportation. However, the total cost of transporting fuel chips was not significantly lower when a depot was set in a port than when fuel chips were directly delivered by truck. Therefore, the delivery system using the milk-run method proposed in the present study must be amended.

There is a reform measure, in which discarded tires are collected from a wide area in Kansai and transported together with those collected in Kanto to reduce the transportation cost. This is a business model in which an industrial park adjacent to the Port of Kobe is utilized.

All discarded tires collected in the Kansai area are treated and turned into fuel chips in an intermediate treatment factory adjacent to a berth in the Port of Kobe, and large amounts of the fuel chips are transported from the berth as one lot by ship.

A collection complex for discarded tires, an intermediate treatment factory to produce fuel chips, and a facility for modal-shift transportation of fuel chips are built in the Port of Kobe. Fuel chips produced at the intermediate treatment factory in the Port of Kobe are transported with those produced in the Kanto and Kansai areas to increase the transportation efficiency as in Figure 7. 


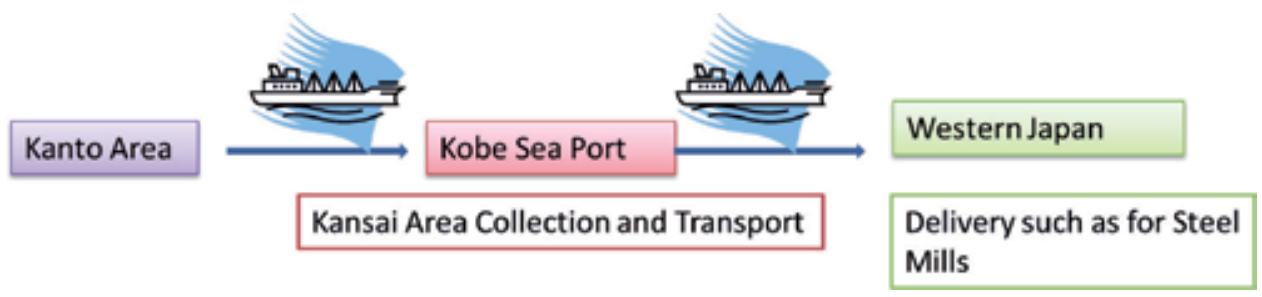

Figure 7.

Image of further improvement.

Furthermore, to improve collection efficiency, wood chips and waste plastics should be collected along with discarded tires. By establishing multiple collection complexes for different types of waste in the Port of Kobe, which has excellent access to Kobe and Osaka cities, marine transportation can happen smoothly.

When the characteristics of the Kansai aria are taken into consideration, that is, since the Osaka and Kobe Cities are geographically close, the establishment of multiple collection complexes for different types of waste in the Port of Kobe can be an effective remedy.

In this study, however, the collection and transport network and the delivery system of thermal products recycled from tires are systematically covered, viewing the total solution. Finally, this study suggests a direction for the effective improvement for the reverse logistics system for discarded tires.

In the future, the delivery system for fuel chips should also be analyzed to determine the possible reduction in environmental load, and should include a number of factors including collection complexes in overseas regions such as China and South Korea in addition to Japan, and consumption areas for the recycled goods.

Moreover, road development and improved living standards in recent years in Asian markets are remarkable. There is also a high possibility of expanding the deployment of discarded tire collection and thermal recycling by fuel chips derived from it to Southeast Asia. Therefore, further studies will consider what types of reverse logistics schemes can be organized when starting from Japan or the final destination.

In addition, a cooperative reverse logistics network will require the establishment of a new scheme while utilizing accumulated knowledge in forward logistics.

\section{Author details}

Kuninori Suzuki ${ }^{1 *}$ and Nobunori Aiura ${ }^{2}$

1 Nihon University, Chiba, Japan

2 Hokkai School of Commerce, Sapporo, Japan

*Address all correspondence to: qw102764@nifty.ne.jp

\section{IntechOpen}

(C) 2018 The Author(s). Licensee IntechOpen. This chapter is distributed under the terms of the Creative Commons Attribution License (http://creativecommons.org/licenses/ by/3.0), which permits unrestricted use, distribution, and reproduction in any medium, provided the original work is properly cited. (cc) BY 


\section{References}

[1] Suzuki K, Aiura N, Wakabayashi K, Karasawa Y. A simulation analysis of recycle product delivery and transport. Journal of the Japan Society of Logistics Systems. 2011;11(1):29-36

[2] Aiura N, Sato K, Karasawa Y, Mizoe M. A study on technique of location selection model considered on productitivity using GA. Journal of JSCE. 2000;17:206 


\title{
Sustainable Supply Chain through Greater Customer Engagement
}

\author{
Amrinder Kaur and Rinku Bhardwaj
}

\begin{abstract}
Climate change has a worldwide impact, and organisations have the greatest responsibility to make a difference through sustainable development as they have the resources, knowledge and reach. Sustainable supply chain in organisations is the need of the hour for holistic development as supply chain involves host of activities including resource conversion and information sharing to add value to end customer. Sustainable supply chain as a concept has evolved due to customer needs/demands as one of the driving forces. Customer engagement needs inclusion in organisations and is relatively undervalued as a tool to drive continuous improvement in supply chains. This chapter will work to build a case of greater customer engagement in supply chain management through organisational communication, interactions, opinions and feedback of customers. The study develops a case of customer engagement for sustainable supply chain through a research using a semistructured questionnaire involving in-depth interviews with founders and decision makers in two mid-tier Indian organisations in health care and in chemical sector in India. Sustainable supply chain through customer engagement aids improved customer/stakeholder retention or loyalty resulting to economic development, positive image building, innovation and better resource utilisation.
\end{abstract}

Keywords: sustainability, supply chain management, customer engagement, customer experience, sustainable practices

\section{Introduction}

Efforts to combat climate change, sinking resources and increasing populations are making countries and organisations work together through series of initiatives at various levels towards a development that can be sustained [1,2]. A decade back, Brundtland Commission report [3] highlighted the need for sustainable development for a positive impact to countries, nations and humanity as continuous development is degrading the environmental resources and essential ecological functions. Sustainable development is to develop in a way that it does not compromise with the needs and livelihoods of future generations.

World Economic Forum (WEF) report further stressed on the need for sustainable development, as the effects of climate change are visible throughout the globe. And without any concrete plan or proactive steps to combat those, the world economy is at risk [4]. And gradually, the effect of climate change is visible at all levels globally with rising sea levels, more hurricanes, flooding, droughts, extreme weather conditions that is disrupting agriculture and affecting the global industrial supply chains as well [5]. 
Investors and scientists are sprucing up their efforts to create a sustainable future and mitigating the effects of climate change to achieve the goals of Paris agreement through forward looking approaches which includes demanding accountability from organisations, governments and engaging to embrace sustainable practices [5].

Organisations play a wider role for a greater positive/negative impact of the initiatives as they have the knowledge and capability to create products/services that add value to various stakeholders. There is an absolute speeding up of the conscious efforts with the increasing demand from various stakeholders especially investors, customers to consider sustainable changes with limited environmental and social implication during operations and production of the product/services [5-8]. The efforts are evident as two major food and beverage organisations committed to protect and preserve fresh water resources throughout their global supply chains [5].

Also as it is reported in 2018 automotive sustainability report of UK automotive industry, organisations are embracing sustainable practices in manufacturing, remanufacturing and recycling of vehicles along with usage of components with a goal to reduce the environmental impact. The automotive organisations in UK particularly are enhancing their efforts through involvement of local communities, re-skilling and training of employees, as part of their operations and global supply chains. With more inclusive growth, these organisations are enhancing customer satisfaction as well with clarity on their core values and practices that are sustainable [8].

Sustainable development is particularly more relevant to organisations and its managers as its customers also including government, employees, etc. are demanding the need for a conscious and a sustainable way of operations and production. Thus increased efforts and solutions for healthy nutrition, green buildings, renewable energy, low carbon transportation and consumption for sustainable development go on [5].

Author like Peter Drucker noted that "If you have no customer it means you don't have any business" [9, 10]. Globalisation, increased market players, newer business models, demanding and connected customers are making it imperative for organisations to find effective means and responsible measures for greater customer engagement and advocacy.

This chapter thus works to build a case of greater customer engagement in supply chain management through organisational communication, interactions, opinions and feedback of customers. The greater customer engagement to

- Build sustainable supply chain management for a development which is sustainable.

Section 2 in the chapter is the literature review followed by research methodology in Section 3. Section 4 is the conclusion followed by limitations of research and future research directions in Section 5. The last section in the chapter is the references.

\section{Literature review}

In an organisation, supply chain management plays a pivotal role in adoption of sustainability-based practices as throughout its lifecycle designing, producing, packaging or transporting by connecting to various vendors account for bulk of activities before the product/services reaches the end customer. Supply chain management involves coordination and collaboration for the flow of information and resources between various channel partners, suppliers and customers themselves $[7,8,11,12]$. Further, regulatory and stakeholder perception especially customer's 
viewpoint has increasingly influenced the issues related to sustainable supply chain management. As is the case with beverage organisations and many retailers particularly wherein the demand for healthy variants, CSR and risk assessment and management of unforeseen activities make a case for adoption of sustainable practices across the supply chain $[5,13]$.

Sustainable supply chain management is essentially a combination of three dimensions viz. the environment, economic and social aspects or the triple bottom line involving environmental, economic and social development $[14,15]$. Sustainable supply chain management is thus achieved by being responsible for environment through economic prosperity with the social upliftment and involvement of the communities and stakeholders involved. It is a collaborated effort involving all the stakeholders $[16,17]$.

Sustainable supply chain management is a complex concept, and as compared to earlier times when one or either two factors were focussed by the organisations, in today's time, it is increasingly defined by the three pillars of sustainability-the environment, economic and social aspects. It can work through integration of economic aspects with complete attention and integrated effort to focus on social equity and ecological conservation $[7,16]$. Sustainability is also a risk management strategy to remain locally identifiable and relevant while expanding globally through continuous improvement, effective stakeholder management with greater employee, customer engagement and retention [17-20].

Also in practice, sustainable supply chain management is a combination of green, lean and resilient ways for sustainable development. Green, lean and resilient sustainable practices include "waste elimination", "supply chain risk management" and "cleaner production" with improved productivity. It is achieved by incorporating all the three aspects of sustainability viz. the social, economic and environmental for channel partners which could be upstream, downstream or for the organisation itself [7].

Elkington [14] exemplifies triple bottom line with activities in supply chain including effective design for reuse and recycle of resources, warehousing and inventory management. Cost savings can also be accrued through reduced packaging, health and safety cost. Sustainable supply chain management due to stakeholder engagement will also lead to improved employee, customer retention through reduced attrition costs and higher motivation, engagement levels for all stakeholders including employees, suppliers and customers.

Further, the facilitators for sustainable supply chain management in an organisation are strategy, risk management, organisational culture and transparency through greater communication and engagement with all the stakeholders especially employees or internal customers, channel partners and external customers [14].

\subsection{Customer engagement in supply chain}

Technologies, innovation, growth and various external factors are bringing tremendous revolution and understanding for stakeholders including customer. The literature identifies that customers are seeking an efficient use of available resources [2] and also may demand products from organisations which are produced on the principles of sustainability [7, 21-23].

Customer engagement through responsible business practices including sustainability is becoming critical for a positive growth in an organisation due to increased consumerism, competition and globalisation. Researchers and practitioners demonstrate that customer experience and enhanced satisfaction also lead to higher revenues for organisations and economic development of the communities and country in general. It is attributed to customer retention, less price sensitivity, 
greater wallet share and positive word of mouth. Customer satisfaction and experience are also drivers of stock performance as customers stay with responsible and engaged organisations [24-26].

Customer loyalty and retention get enhanced with greater customer engagement and thus are important for business success. As when the customers stay with organisations, they lead to revenues or economic development. Ahi et al. [25] further highlight that "if business managers can cultivate better returns from investing in the satisfaction of their customers, investors should be able to reap similar returns”.

Leading organisations as well are acknowledging that there is direct correlation between the success of its customers and the profits, revenue and future growth. It makes an absolute case for profitability and sustainability to become synonymous with each other and to further involve practices incorporating sustainability or sustainable practices [27].

The literature identifies that global organisations are moving towards product service systems wherein the products are bundled with service for a greater customer life time value and engagement [28]. Bundling services with products are getting prioritisation and helping organisations to further improve revenues and profitability.

Customer experience management involves a strategy of customer centricity [28], wherein the organisational focus on customer completely aligns its processes, people, product, place and policies on the basis of the customer feedback. This is done by engaging the different organisational concepts, structure to customer needs and disseminating the information across all hierarchies to influence the decisionmaking for greater customer satisfaction [29]. In all, customer centric organisation draws customer perspective at different interaction points with the organisation to create an engaged and everlasting experience.

Customer engagement through customer feedback has also been the driving force for adoption of sustainability as a business practice for risk management and for a continuing relationship with customers. Organisations too are working to consider the impact on overall life cycle of their product and work on to build relationships which are creating advantages both for the customer and the respective organisations [24]. Supply chain leaders especially in retail increasingly understand the importance of customer experience through customer engagement in their supply chain and have been working through various measures to integrate, assimilate and gather real time data for effective supply chain deliveries. Recent research suggests that supply chain managers are working to integrate customer experience in their operations [30].

Customer engagement for greater customer experience management is becoming more and increasingly important particularly in sectors where products are commodities and the provider has little involvement with the end consumer or missing emotional connects with its customer. Customer engagement drives the customer satisfaction which is dependent on overall perception and value in use. Customer experience management begins before customers' starts using service/product or start interacting with a brand and continues long after the engagement.

Customer engagement is important but with ever changing dynamics of customer behaviour and their demands to receive their product/service instantly with quality and efficiency, developing a good customer experience strategy is becoming tedious task $[26,31]$.

Research at Forrester identifies that $84 \%$ brands got good scoring or worse from the customers for their product and services [26]. Customer engagement for internal and external customer can help to enhance loyalty through value to the price 
given and quality identified for the product/service across the supply chain [29]. Customer engagement for sustainable supply chain management practices will also support to build trust and brand connection for the customer leading to willingness to pay a price premium for the product and services utilised $[32,33]$.

Sustainable supply chain management practices will support organisations through growth, profit and innovation. Engaging with the customer helps an organisation to understand the customer's demands, perceptions, and expectations to tune in the products and services, deliveries, product design, product cycles as per demand and customer preferences for increased profits [31-36, 44].

\section{Research methodology}

Qualitative research is used to further understand and build a case for sustainable supply chain management through customer engagement in two mid-tier Indian organisations in health care and in chemical sector in India.

Qualitative research in social sciences involves the process of inquiry and understanding of phenomenon within their naturalistic setting. In the qualitative research, the focus is on individuals, societies, communities and their behaviours, perceptions and communication. Qualitative research is based on the assumption of understanding phenomena through subjective process of inquiry rather than the objective ones [13,37,38].Qualitative research particularly focuses on "why" of a phenomenon through the process of inquiry with individuals to understand their preferences and behaviours.

This qualitative research uses case study method. Case study methodology can be used for both quantitative and qualitative researches and is done through a detailed study of the subject in their natural setting. Case study aims to understand an individual, event or phenomena and details it through its natural setting. Case study methodology utilises inductive method of inquiry by starting with questions and collecting data related to the case in context of research. The literature further identifies that case study supports in-depth exploration of an event, a problem, an institution, an individual, policy, process and so forth to understand the underlying context and perceptions of the case in focus [13, 37-39].

Case study method through interviews is an effective social science research method to provide in-depth explanations and outcomes through observations and reconstruction utilising both quantitative and qualitative data [39]. Researchers also elaborate that interviews are an effective methodology in qualitative research to provide holistic view on facts and issues in question [39].

In this qualitative research, a semi-structured questionnaire had been prepared to keep the focus on conversations and to effectively utilise the time of respondents.

For preparing the questions to gauge/understand the sustainable supply chain management practices of organisations, GRI [40,41] factors or variables were used along with some questions on customer engagement. GRI or the global reporting initiative $[40,41]$ is a multi-stakeholder process, through which organisations communicate their progress and initiatives for sustainability [41-43].

GRI is an independent institution started in 1997 by the Coalition for Environmentally Responsible Economies (CERES). It became independent in 2002 and is collaborating centre of the United Nations Environment Programme (UNEP) and Global Compact [40-43]. GRI works and disseminates sustainability reporting guidelines, which are utilised by organisations to report their practices and other impacts on product/services and processes for the triple bottom line that is economic, environment and social factors/variables. 


\begin{tabular}{llc}
\hline Industry & Job title & Number of responses (n) \\
\hline Healthcare & Founder, Managers & 4 \\
\hline Chemical & Director, Managers & 8 \\
\hline
\end{tabular}

Table 1.

Demographic profiling for the respondents.

Executives of two mid-tier organisations in India were contacted and interviewed. The mode of interviews with executives and decision makers in two organisations was either through face to face or telephone. Questions had been shared in advance with majority of respondents as per their request. And then as per the preset schedule, the respondents had been contacted either through face to face or telephonic interview mode.

The revenue for two mid-tier organisations is around 10 crore (INR) for the healthcare organisation and more than 10 crore (INR) for the chemical industry. The executives were founders and decision makers involved in health care and chemical industry in India. The semi-structured questionnaire prepared was used along with the collection of verbatim of executives for making the interview sessions to be more effective.

In the healthcare industry, all the four interviews were done face to face, and in the chemical industry, 50\% interviews were face to face and rest was through telephone as per the convenience of the respondents.

The data collected from the face to face and telephonic interview sessions were insights from in-depth discussion on customer engagement used for sustainable supply chain management. The demographic profiling of the respondents is shown in Table 1.

Every interview lasted for around 40-50 min and the key points have been summarised (Table 2).

In both the organisations, $80 \%$ of respondents agreed that customer experience and sustainability are the one of the most important arenas for them to work on. They are focussed for sustainability-based practices and would like to include customer engagement through organisational communication, interactions, opinions and feedback of customers in their operation and supply chain. Agility, innovation, flexibility and responsible practices are the key differentiators to compete in the market place today.

Majority of respondents (70\%) also agreed that in spite of the focus there are numerous challenges that need newer approaches and innovative practices for greater inclusion. As per the respondents,

- Mapping of customer engagement with expectations and deliverables across the entire supply chain will need time and some innovative practices.

- Traditional metrics to measure sustainable supply chain performance are not sufficient.

- $60 \%$ of respondents believed that current technologies do not support much to inculcate customer engagement with sustainable supply chain management.

- Sustainable supply chain management will definitely need top management commitment along with processes with the customer engagement as the input.

- Aligning the teams and various partners still need work. 


\begin{tabular}{ll}
\hline Variable/question & Summary of responses \\
\hline What is customer engagement for you? & Managing and maintaining a relationship with \\
customer & - Interacting and having a feedback from customer to \\
& keep working on \\
- & A positive interaction to understand and improve \\
& Interacting and having a mutually beneficial \\
& relationship \\
\hline
\end{tabular}

How do you engage with your customers? A little elaboration on may be the kind of channels, etc.?

\begin{tabular}{ll}
\hline $\begin{array}{l}\text { Is sustainable supply chain management an } \\
\text { important criterion in your organisation? }\end{array}$ & $\begin{array}{l}\text { Yes, it is an important criteria for both the organisations } \\
\text { as per all the respondents }\end{array}$ \\
\hline $\begin{array}{l}\text { Is customer engagement an active part of your } \\
\text { sustainable supply chain management? }\end{array}$ & $\begin{array}{l}\text { Yes, it is an important criterion for both the } \\
\text { organisations as per all the respondents but the mode of } \\
\text { engaging with customer is still evolving. }\end{array}$ \\
& $\begin{array}{l}\text { Both the organisations agreed that they are } \\
\text { experimenting and learning to understand what it } \\
\text { means for their organisation. }\end{array}$ \\
\end{tabular}

Where do you think, you are with respect to customer engagement for your sustainable SCM?
All respondents from both the organisations believed that they just started out and are evolving and learning, working to integrate a greater customer engagement in their organisation.

\footnotetext{
How do you ensure that strategic discussions about the supply chain include the implications of changing customer and consumer demands-both today and into the future?
}

Engaging with customers at regular interval to understand their needs and concerns.

The engagement is through distributors and surveys which they roll out periodically. But they need to put some
How do you understand and enable the requirements regarding greater customer engagement in your supply chain? system in place for actively engaging to seek feedback.

- Creating agility and flexibility in the entire supply chain of products

- Communicating the quality and other documentation needs with the partners, suppliers and vendors

- Planning for contingencies

- Regulatory and compliance mechanism across the entire lifecycle of product

How do you think is the vendor community contributing about customer experience as a core element of the future supply chain?
- By working to comply with the regulatory and other compliance needs of the organisations.

- Working diligently to create/product and services to cater to wider needs of the respective organisations.

- Innovating to cater and for the ease of the respective client organisation

Can you please help us understand how customer engagement particularly is affecting three (economic, environment and social factors) of supply chain management for your organisation

\begin{tabular}{|c|c|}
\hline $\begin{array}{l}\text { Economic factors } \\
\text { Do the decisions get impacted by customer } \\
\text { engagement for sustainable supply chain, for } \\
\text { economic factors related to economic decisions, } \\
\text { market presence and indirect economic impacts }\end{array}$ & $\begin{array}{l}\text { - The respondents of chemical organisation give lot of } \\
\text { diligence to understand and evaluate if their vendors } \\
\text { are economically sustainable, have healthy balance } \\
\text { sheets and have good market presence. It is a part of } \\
\text { their risk assessment. } \\
\text { - The respondents from healthcare organisation } \\
\text { elaborated that they do not focus much on economic } \\
\text { viability and sustainability of their vendors. } \\
\text { Majority of respondents in both the organisations } \\
\text { believe that cost and margins are important in their } \\
\text { business and decisions are driven by it. }\end{array}$ \\
\hline
\end{tabular}




\begin{tabular}{|c|c|}
\hline Variable/question & Summary of responses \\
\hline $\begin{array}{l}\text { Environment factors } \\
\text { Do the decisions get impacted by customer } \\
\text { engagement for sustainable supply chain, for } \\
\text { environment factors related to } \\
\text { Materials } \\
\text { Energy } \\
\text { Water } \\
\text { Biodiversity } \\
\text { Emissions } \\
\text { Effluents and waste } \\
\text { Products and services } \\
\text { Compliance } \\
\text { Transport } \\
\text { Overall } \\
\text { Supplier environmental assessment } \\
\text { Environmental grievance mechanisms }\end{array}$ & $\begin{array}{l}\text { The respondents of chemical organisation give } \\
\text { importance to environmental factors and compli- } \\
\text { ance. Though they believe they still need little more } \\
\text { compliance and work together with their vendors, } \\
\text { partners on reducing the impact on environment. } \\
\text { But they started the journey utilising ISO compli- } \\
\text { ance including for logistics, transport and emission } \\
\text { standards. } \\
\text { - The healthcare organisation had been focussing on } \\
\text { compliance information from their vendors and } \\
\text { suppliers through ISO and will need more active } \\
\text { engagement to assess the environmental impact. }\end{array}$ \\
\hline $\begin{array}{l}\text { Social-fair labour practices } \\
\text { Do the decisions get impacted by customer } \\
\text { engagement for sustainable supply chain, for } \\
\text { social-fair labour practices related to } \\
\text { Employment in supply chain, } \\
\text { Labour/management relations in supply chain, } \\
\text { Occupational health and safety in supply chain, } \\
\text { Training and education in supply chain, } \\
\text { Diversity and equal opportunity in supply chain. }\end{array}$ & $\begin{array}{l}\text { - Respondents of both the organisation agreed that } \\
\text { that fair social labour practice of their suppliers and } \\
\text { other channel partners is not much on their agenda. }\end{array}$ \\
\hline $\begin{array}{l}\text { Social-human right practices } \\
\text { Do the decisions get impacted by customer } \\
\text { engagement for sustainable supply chain, } \\
\text { for social-human right practices related } \\
\text { to investment in supply chain, non- } \\
\text { discrimination in supply chain, freedom of } \\
\text { association and collective bargaining in supply } \\
\text { chain, child labour in supply chain, forced/ } \\
\text { compulsory labour in supply chain, security } \\
\text { practices in supply chain. }\end{array}$ & $\begin{array}{l}\text { Both the organisation respondents agreed that they are } \\
\text { not working much on the same. }\end{array}$ \\
\hline $\begin{array}{l}\text { Social-Society } \\
\text { Do the society decisions get impacted by } \\
\text { customer engagement for sustainable supply } \\
\text { chain, for society related to local communities, } \\
\text { anti-corruption practices, public policy, } \\
\text { anti-competitive behaviour, compliance of laws, } \\
\text { supplier assessment for impacts on society, and } \\
\text { grievance mechanisms for impacts on society }\end{array}$ & $\begin{array}{l}\text { Both the organisation respondents are not working } \\
\text { much on the same. But they do take anti-corruption } \\
\text { practices, public policy, anti-competitive behaviour, } \\
\text { compliance of laws, etc. seriously. And if anything } \\
\text { undue catches their attention, they take suitable action. }\end{array}$ \\
\hline $\begin{array}{l}\text { Social-product responsibility } \\
\text { Do the decisions get impacted by customer } \\
\text { engagement for sustainable supply chain, for } \\
\text { product responsibility related to customer's } \\
\text { health and safety, product and service labelling, } \\
\text { marketing communication and customer privacy }\end{array}$ & $\begin{array}{l}\text { For both the organisations, compliance to quality and } \\
\text { other regulatory norms is important. }\end{array}$ \\
\hline
\end{tabular}

Table 2.

Data collected through the questionnaire.

\section{Conclusion}

Sustainable development is getting more prominence in today's time with changing dynamics in businesses, and it is further amplified by shrinking resources, increasing population, global risk management and greater stakeholder interest 
and activism. Government, customers, investors, partners and so forth seek more responsible organisations that are transparent with their policies and practices.

Globally, organisations particularly are working on long-term strategies, practices to inculcate sustainable practices in their processes, product/services throughout the complete product life cycle including supply chain as well. Stakeholder particularly customer engagement can lead to amplification of practices, methodologies and innovation for more responsible practices for an inclusive growth. More so sustainable supply chain management practices will lead to more responsible behaviour and greater stakeholder engagement for the businesses as well.

The research involving two mid-tier organisations works to understand how customer engagement is contributing to sustainable supply chain management. Qualitative research through interviews with decision makers in two case organisations maps the challenges they face and the current focus of the management and decision makers.

In both the organisations, inclusion of customer engagement and sustainable supply chain management practices is at a nascent stage. Decision makers understand the relevance of sustainable supply chain practices and customer experience/ engagement but are struggling with legacies of cost and margins, as these are still important parameters to drive success. The two case organisations are evolving processes, systems and culture for sustainable development through greater customer engagement.

- Innovation and work towards methodologies and inclusive practices can help to capture customer feedback, opinions about products and services to further inculcate sustainable practices across the entire supply chain/customer life cycle

- Review and identification of metrics and measures can support to track and monitor the performance around sustainable supply chain management practices through customer engagement.

- Investment and innovative solutions through technology as per current needs and requirements will aid sustainable supply chain management. The processes and practices can support to provide holistic view of supply chain.

- Commitment across the board is to be driven through cultural shift initiatives. Leadership commitment will ensure that there is right context provided to entire organisation.

- Reengineering of existing processes with alignment of all stakeholders/teams can enhance the efforts to adapt sustainability-based practices.

Sustainable supply chain management practices are important for the continuous success of business, communities and countries. Customer engagement can play an important part to enhance the sustainable supply chain management practices. Sustainability cannot be handled in segregated manner and has to be part of operations and decision-making throughout the entire lifecycle with integrated supply chain, and customer engagement can be a driver to create the change needed which will be success for the business and customers all along.

\section{Limitations of research and future research directions}

This chapter is a qualitative exploratory research to create a case for sustainable supply chain management practices through customer engagement. Researchers can 
further develop the work wherein quantitatively the effect of customer engagement on supply chain management practices could be measured for greater inclusion.

Researchers can also identify the causes through appropriate hypothesis to support/understand sustainable supply chain management practices for the aid of practitioners through customer engagement.

\section{Acknowledgements}

We are thankful to all our respondents for taking out time from their schedules to support us further in the research.

\section{Author details}

Amrinder Kaur* and Rinku Bhardwaj

Pink Guava Consulting Services, Gurgaon, India

*Address all correspondence to: amrinderkaursaini@gmail.com

\section{IntechOpen}

(C) 2019 The Author(s). Licensee IntechOpen. This chapter is distributed under the terms of the Creative Commons Attribution License (http://creativecommons.org/licenses/ by/3.0), which permits unrestricted use, distribution, and reproduction in any medium, provided the original work is properly cited. (cc) BY 


\section{References}

[1] COP-21. 2015. Available from: http:// climateparis.org/ [Accessed: December 22, 2015]

[2] Cliffe S. What Climate Change Means for Business Before and After Paris. USA: Harvard Business Review; 2015. Available from https://hbr. org/2015/12/what-climate-changemeans-for-business-before-andafterparis?utm_source $=$ twitter\&utm_ medium $=$ social\&utm

campaign=harvardbiz [Accessed: December 22, 2015]

[3] WCED. Our Common Future. Oxford: Oxford University Press; 1987

[4] World Economic Forum. Redesigning Business Values-A Road Map for Sustainable Consumption. Geneva: World Economic Forum. 2010. Available from: http:// www3.weforum.org/docs/WEF_ RedesigningBusinessValue_Sustainable Consumption_Report_2010.pdf [Accessed: August 20, 2014]

[5] Luber M. We Must Be 'All Hands On Deck' When It Comes To Climate Change. 2018. Available from: https://www.forbes.com/sites/ mindylubber/2018/10/18/we-must-beall-hands-on-deck-when-it-comesto-climate-change/\#732b9d4c5122 [Retrieved: November 2, 2018]

[6] Seuring S, Muller M. From a literature review to a conceptual framework for sustainable supply chain management. Journal of Cleaner production. 2008;16:1699-1710

[7] Ahi P, Searcy C. An analysis of metrics used to measure performance in green and sustainable supply chains. Journal of Cleaner Production. 2013;85:360-377

[8] Agarwal P. Focus on Sustainability and Diversity to Break Traditional
Boundaries. 2018. Available from: https://www.forbes.com/sites/ pragyaagarwaleurope/2018/10/27/ creating-diversity-in-blockchainand-disrupting-the-auto-industry2/\#5b7968cf2ad6 [Retrieved: November $2,2018]$

[9] Carter CR, Easton PL. Sustainable supply chain management: Evolution and future directions. International Journal of Physical Distribution and Logistics Management. 2011;41(1):46-62. DOI: 10.1108/09600031111101420

[10] Smith S, Wheeler J. Managing the Customer Experience: Turning Customers into Advocates. US: Financial Times Prentice Hall; 2002

[11] Gupta S, Palsule-Desai O. Sustainable supply chain management: Review and research opportunities. IIMB Management Review. 2015:234-245

[12] Govindan K, Azaevedo SG, Carvalho H, Cruz-Machado V. Impact of supply chain management practices on sustainability. Journal of Cleaner Production. 2014;85:212-225

[13] Walker H, Jones N. Sustainable supply chain management across the UK private sector. Supply Chain Management: An International Journal. 2012;17:15-28. DOI: 10.1108/13598541211212177

[14] Elkington J. Triple bottom line revolution: Reporting for the third millennium. Australian CPA. 1999;69(11):75-79

[15] Carter CR, Rogers DS. A framework of sustainable supply chain management: Moving toward new theory. International Journal of Physical Distribution and Logistics Management. 2008;38(5):360-387

[16] Seuring S. A review of modeling approaches for sustainable supply 
chain management. Decision Support Systems. 2013;54:1513-1520

[17] Ahi P, Searcy C. Assessing sustainability in the supply chain: A triple bottom line approach. Applied Mathematical Modelling. 2015;39:2882-2896

[18] Generation Investment Management. Sustainability Trends Report; 2017. Available from https://www.generationim.com/ sustainability-trends/sustainabilitytrends-2017/\#sustainability-trendsreport-download [Accessed: August 15, 2018]

[19] Kiron D, Kruschwitz N, Haanaes K, Reeves M, Kehrbach SKF, Kell G. Joining Forces: Collaboration and Leadership for Sustainability. USA: Massachusetts Institute of Technology; 2015

[20] Yilmaz AK, Flouris T. Managing corporate sustainability: Risk management process based perspective. African Journal of Business Management. 2010;4(2): 162-171. Retrieved from: http://www. academicjournals.org/journal/AJBM/ article-full-textpdf/D666F9E21165

[21] Smith A. Consumer Engagement in Sustainability-Why It Matters? 2013. Available from: https://www. sustainablebusinesstoolkit.com/whyconsumer-engagement-matters-insustainability/[Accessed: September 9, 2018]

[22] Hassini E, Surti C, Searcy C. A literature review and a case study of sustainable supply chains with a focus on metrics. International Journal of Production Economics. 2012;140:69-82

[23] Labuschagne C, Brent AC, Erck RPGV. Assessing the sustainability performances of industries. Journal of Cleaner Production. 2005;13:373-385
[24] Dauvergne P, Lister J. Big brand sustainability: Governance prospects and environmental limits. Global Environmental Change. 2012;1(3):36-45

[25] Ahi P, Jaber MY, Searcy C. A comprehensive multidimensional framework for assessing the performance of sustainable supply chains. Applied Mathematical Modelling. 2016;40:10153-10166

[26] American Customer Satisfaction Index (ACSI). The Science of Customer Satisfaction. Available from: http:// www.theacsi.org/about-acsi/thescience-ofcustomer-satisfaction [Accessed: February 02, 2017]

[27] Fornell C. The Satisfied CustomerWinners and Losers in the Battle for Buyer Preference. US: Palgrave Macmillan; 2007. pp. 3-4

[28] Pepsi-Co. Sustainability Reporting. USA: PepsiCo. 2014. Retrieved from: http://www.pepsico.com/docs/album/ sustainability-reporting/pep_csr14_sus_ overview.pdf

[29] Adrodegari F, Bonetti D, Saccani N. A Framework to Assess the Level of Customer Centricity in Manufacturing Companies. 2017. Retrieved from: https://www.researchgate.net/ publication/320081732

[30] Davey N, MAcGillavery K, Wilson A. 2017. A Framework for Measuring \& Improving CX: Customer Experience Management Maturity Model and Questionnaire. Retrieved from: https://www.researchgate. net/publication/316284094_A_ framework_for_measuring_imp roving_CX_Customer_Experience_ Management_Maturity_Model_and_ Questionnaire

[31] Burns M, Gozala ME, Zoia G, Hartig K. The Customer Experience Management Maturity Model. US: Forreseter Research; 2016 
[32] Eft \& Convey. Redefining Final

Mile Delivery in the Age of the

Customer. 2016. Available from: https://

www.getconvey.com/wp-content/

uploads/2018/03/EfTransport-Convey-

Whitepaper-FINAL.pdf [Retrieved:

September 20, 2017]

[33] Kim H, Lee CW. The effects of customer perception and participation in sustainable supply chain management: A smartphone industry stud. Sustainability. 2018;10:2271. DOI: 10.3390/su10072271

[34] Klaus P, Maklan S. Towards a better measure of customer experience. Journal of Market Research. 2013;55(2):227-246

[35] Voltas Case Study. 2006. Available from: http://www.rediff. com/money/2006/apr/05spec2.htm [Retrieved: October 24, 2017]

[36] Lay G. Servitization in Industry. Germany: Springer; 2014. DOI: 10.1007/978-3-319-06935-7

[37] Tellis W. Introduction to Case Study. The Qualitative Report. Vol. 3, Issue 2. 1997. Available from: http://www. nova.edu/ssss/QR/QR3-2/tellis1.html [Retrieved: August 15, 2018]

[38] Qualitative Research. What Is Qualitative Research? Available from: https://nursing.utah.edu/ research/qualitative-research/what-isqualitative-research.php [Retrieved: November 2, 2018]

[39] Starman AB. The case study as a type of qualitative research. Journal of Contemporary Educational Studies. 2013;1:28-43. Available from: http:// www.sodobna-pedagogika.net/ wp-content/uploads/2013/03/Starman1. pdf [Retrieved: November 3, 2018]

[40] Global Reporting Initiative. 2002. Available from: www. globalreportinginitiative.org [Accessed: August 08, 2013]
[41] Global Reporting Initiative. 2015. Available from: https://www. globalreporting.org/resourcelibrary/ GRIG4-Part1-ReportingPrinciples-andStandard-Disclosures.pdf [Accessed: December 12, 2016]

[42] Tata Consultancy Services. Corporate Sustainability Report-2013. Available from: https://www.tcs.com/ content/dam/tcs/pdf/discover-tcs/ investor-relations/corporatesustainability/TCS-CorporateSustainability-Report-2012-13.pdf [Accessed: July 15, 2015]

[43] Sahay A. Environmental reporting by Indian Corporations. Corporate Social Responsibility and Environmental Management. 2004;11:12-22. DOI: 10.1002/csr.051

[44] Klaus P, Maklan S. Towards a better measure of customer experience. Journal of Marketing Research. 2011;53(6):771-792. DOI: 10.2501/ IJMR-53-6-771-792 



\title{
Green Supply Chain Management: A Precursor to Green Purchasing
}

\author{
Kenneth Mathu
}

\begin{abstract}
The chapter's focus is on an enterprise collaboration with the members of the value chain and the use of technology to enhance integration. These factors are attributes of supply chain management (SCM). When emphasis is placed on lean and agile supply chains, closed-loop supply chains, reverse logistics, and the practice of just in time (JIT), the operation is transformed to green supply chain management (GSCM). JIT reduces outsourcing of resources, has controlled production and transportation, and uses distribution centers to expedite the distribution process. The utilization of the returned products in reverse logistics for reuse, recycle, and remanufacturing reduces dumping and environmental degradation. The returned materials become additional resource which is value-added to the enterprise. Ultimately, this is a cost saving and a contribution to the enterprise's bottom line and sustainability.
\end{abstract}

Keywords: collaboration and integration, environment, green supply chain management, lean and agile, reverse logistics

\section{Introduction}

The green supply chain management (GSCM) emerged from the conventional supply chain management (SCM) in the last two decades or so, and supply chain itself is just over a generation old. Supply chain evolved from discussions initiated by a group of professional consultants in the early 1980s [1]. The deliberations reached a peak with the publication of Michael Porter's book, The Competitive Advantage: Creating and Sustaining Superior Performance [2]. In the book, Porter emphasized that industries could perform various primary and support activities that could add value to the products/services that in turn could add value for customers. The linkages of these activities that added value to the products/services that an organization produces was Porter's description of "value chain." Porter described the support services as inbound logistics, operations, outbound logistics, marketing, sales, and services. Inbound logistics is the supply chain process of supplying raw materials to the focal manufacturer. The transformation of raw materials by the focal manufacturer into finished products or work in progress is referred to as operations. The distribution of the manufactured goods to fulfill customer orders is outbound logistics. The marketing process establishes the demand of products/ services by customers. On understanding the customer needs, the sales process is pursued to take the customer orders. Subsequently, service provisions ensue in fulfilling customer's product/service orders. 
The global supply chain forum of 1999 defined supply chain as "an integration of procedures from suppliers to consumers to provide products/services and information in order to add the values of the customers and the related roles" ([3], pp. 194-205).

Supply chain management covers industry planning and control of activity that relate to trade, exchange and logistics management, and collaboration among suppliers, agents, and new customers. With increased customer awareness and more stringent regulations, industries have started to integrate environmental factors in all sectors of the organization. The industries have started integrating green technologies in product designs, production, and distribution which is a gradual trend of shifting toward environmentally friendly supply chain (SC). These efforts and the desire to incorporate "extended production responsibility" (EPR) as pertains to environmental impacts are the precursors to the evolution of "green supply chain management" (GSCM) ([4], p. 4).

The theory of GSCM was developed in the 1990s, but emphasis on green production by most industries commenced from around 2000. With the growing consciousness about the environment, SC complexity and the scale of GSCM technologies also increased. GSCM is defined as "a supply chain that considers environmental impacts on its operations and takes action along the supply chain to comply with environmental safety regulations and communicates this to customers and partners" ([5], p. 73). GSCM integrates all the aspects of environmental management which includes reverse logistics. Reverse logistics entails "a supply chain dedicated to reverse flow of products and materials for the purpose of returns, repair, remanufacture, and/or recycling." The organizations that proactively manage reverse logistics have added financial benefits to their bottom line ([6], p. 619).

\section{Green supply chain management (GSCM)}

Green supply chain management extends across the organization, its trading partners, and processes involved in purchasing, manufacturing, materials management, distribution, and reverse logistics. The GSCM ensures that there is sharing of environmental responsibility in supply chain at every stage and process to ensure that the adverse impact on the environment is minimized ([7], p. 508).

The American leading global retailer Walmart, provide green materials. Its goals among others include being supplied $100 \%$ by renewable energy, to produce zero waste and to sell products that sustain people's health and environment. The retailer has integrated a supplier sustainability index into its business to measure the vendor product offerings [8].

\section{Impact of GSCM on industry}

Industry evaluation is done through product/service analysis called "life cycle assessment" (LCA). LCA helps designers at the beginning of product design to identify techniques that ensure that the product components and designs are to the environmental standards. Standards are the set of the amount of energy and natural resources utilized, the amount of emissions caused by air and water pollution, and the waste products resulting from the consumption of the product output ([5], p. 93).

Industries strive through GSCM system to evaluate the green performance of suppliers, assess the quality of green product, and direct overall management of suppliers. Information technology (IT) is used to sort out the green supply chain 
(GSC) issues between the organization and the value chain partners. The process involves gathering all existing material systems, information management systems, and process operation systems and integrating all the green requirements into tasks and procedures to achieve greening. The last step is to ensure that the overall SC conforms to the standard of GSCM through management systems, production processes, technique standards, verification of work, and analysis of product components [9].

A 2017 empirical study in the developing countries focusing on Pakistan's manufacturing firms using exploratory factor and simultaneous analysis on five independent variables of GSCM practices established that four of them were statistically significant in predicting the organizational performance. The four predictable variables were ecological product designs, green manufacturing, green information systems, and cooperation with customers, and the variable that failed the test was green purchasing [10]. Another research in Pakistan's manufacturing firms investigated their economic and environmental performance and established that green practices such as ecological design of products, green transport, and distribution positively impacted on the environmental performance [11]. These distinctive examples illustrate how GSCM implementation would drive sustainability in enterprises and become a conduit for the unfolding Fourth Industrial Revolution (4IR).

\section{Benefits of GSCM}

The benefits of GSCM encompass green initiatives such as green materials, green production, reverse logistics, closed-loop supply chains, sustainability and green initiatives, and green procurement to ensure sustainability for the present and future generation. Wang and Gupta ([4] p. 8) described six benefits of GSCM in client/supplier relationship as follows:

1. Increased interaction between client and supplier: the process of understanding the client's needs and wants, providing opportunity for future product development and encouraging suppliers to continuously improve on their products/ services.

2. Collaboration between the company (client) and the supplier to create innovative product design: innovation through identifying substitute materials, creating energy-saving design, and upgrading infrastructure to increase efficiency.

3. Requirement for supplier to provide environmental information: to ensure product conformance with environmental standards, identification of hazardous component in the product, mode of transportation, and weight of products, among others.

4. Client and supplier collaboration in creating green product design: collaboration development of product design and the client to provide the supplier with product requirements that would meet environmental standards.

5. Auditing the supplier's green performance: the client prepares a checklist of green management requirements or environmental audit management system to ensure the supplier satisfies the product requirements that help the client achieve the corporate social responsibility (CSR) goals. 
6. Supplier initiative in standardization process: taking initiative to install own testing equipment to ensure meeting the standard of green purchasing.

\section{Environmental design}

Environmental design involves designing a product in a way that the environmental impact is minimized throughout the product life cycle. Such product is a "green product," and it is produced through a "green manufacturing" process. Green product is a good or service that minimizes external costs and pollution, and green manufacturing is a process of producing a good or service that minimizes external cost and pollution. The process includes design for reuse, disassembly, and remanufacture [5].

In pursuit of green manufacturing, governments, corporations, and societies must commit to rethink, reduce, reuse, recycle, and redesign products to achieve reduction of waste and pollution and sustainable quality of life. Hence, environmental concern is about taking cognizance of green products related to environment protection.

Presently, two techniques are used to analyze and improve the design of products for making them environmentally friendly. The first involves analyzing the effects of design efficiency of a product on the environment through its end of life (EOL), disassembly, and disposal. The second involves inserting sensors into products during their production phase to provide information on the condition and version of the main components before disassembling them at the end of life ([4], p. 37).

Environmental protection has continued to grow as a major global concern with more organizations paying more attention in ensuring that green standards are adhered to at all levels of the value chain. This entails involvement of suppliers of raw materials, manufacturers, distribution process, and social welfare that is referred to as "green value chain." The green value chain framework is built based on future trends and environmental requirements for sustainable design ([12], p. 431).

\section{Green materials}

Green materials are used in green engineering, whereby products are designed and produced using minimum amount of resources, and the process that is used to produce them has a minimum impact on the environment. Thus, green materials refer to the minimum resources used to make a product/ service. They comprise utilization of minimum raw materials and renewable energy that has minimal carbon emissions. The green materials emanate from the minimization of material's content and types, energy consumption during usage, scraps during production, disposal at products' end of life, packaging materials, and energy consumption during product development and production stages ([12], p. 301).

The planet earth has different types of materials used for various applications. They comprise metals (steel, aluminum, titanium), ceramics (porcelain, mineral glass, and metallic oxides), polymer thermoplastics (acrylic and polypropylene), polymer thermosets (epoxy and polyurethane), elastomers (isoprene, neoprene, and styrene butadiene rubber), natural organic materials (wood, bamboo, and cotton), and composites (graphite epoxy, polyester, and fiberglass) [13]. 


\section{Green production}

Green production is a method of producing a good or service that minimizes external costs and pollution. The process involves design for reuse, design for disassembly, and design for remanufacture. Green productivity focuses on enhancing productivity and environmental performance for sustainable development in the industry to achieve competitive advantage. The industry has not only increase product value; it also needs to use the value chain. Thus, the critical point is to decrease the environmental impact throughout the value chain, from raw material supply to the final product. The environmental impact emanates from energy use, consumption of natural resources, and pollution-related problems [14].

The environment is damaged by the exploitation of the global natural resources for economic development. The process causes pollution that spread to the entire world via wind and water. As a result, many countries under the auspices of the United Nations Framework Convention on Climate Change (UNFCCC) have sought to combat carbon emissions which have been proven by scientists as a contributor to the global phenomenon of climate change or global warming [15].

Since the advent of green manufacturing, manufacturers are required to be responsible for the logistics process from production planning to product recovery and greenhouse gas emissions, that is, being responsible for the entire life cycle of products/services. That includes responsibility over the returned products' repair, refurbishing, remanufacturing, cannibalization, recycling, and disposal ([16], p. 130).

\section{Sustainable development}

Sustainable development is defined as "development that meets the needs of the present without compromising the ability of the future generations to meet their own needs" [17]. This definition was initiated during the United Nations "World Commission on Environmental and Development" (WCED) summit in 1987.

Sustainable development is characterized by energy consumption and production, greenhouse gas (GHG) emissions, and climate change. As these issues are interrelated, they are better considered in an integrated manner and linked to economic, social, and environmental implications. Scientists have proven that the increased consumption of fossil fuels (oil, coal, and gas) as energy source for development adversely affects the global climate. The ensuing severe climatic conditions lead to global warming and heavy rain with devastating floods and melting of ice in the polar region raising the seal level. As the price of oil rises with increasing demand, the cost of production of goods and services increases, affecting the supply chain costs. In view of these increasing costs, solutions in the form of resource efficiency and technology innovation emerge as opportunities for reducing costs and increasing competitiveness and employment which are critical factors to managing an effective supply chain ([7], p. 402).

\section{Sustainability and green initiatives}

Sustainability and green initiatives focus on dematerialization, detoxification, and decarbonization processes that culminate into 4Rs (reduction, redesign, reuse, and remanufacture) ([16], pp. 83-84). 
Dematerialization: it refers to industries' attempt to reduce materials or time needed to produce and deliver products/services required by the customers.

Detoxification: it is the reduction of poisonous and hazardous materials contained in industrial waste during processing of natural raw materials in industries to produce products/services. The poisonous materials which are in the form of industrial waste and pollution contaminate in the environment. The degradation of the environment threatens the living condition of the organisms in the ecosystem.

Decarbonization (de-energization): it is the reduction of greenhouse gas (GHG) emissions in the atmosphere that occur when burning fossil fuels for electricity generation. The most abundant GHG is carbon dioxide that has been proven by environmental scientists to be a contributor to the global phenomenon of climate or global warming.

To achieve sustainable goals or greening the environment, redesigning of products is crucial, reducing energy consumption (use of renewable energy), reusing the returned products, and remanufacturing the damaged products ([18], pp. 64-66).

\section{Supply chain operations reference (SCOR) model}

Supply chain operations reference (SCOR) model is a diagnostic benchmarking and improvement process for supply chain operations. The SCOR model was established in 1996 as a tool for manufacturing and service organizations. It is managed by Supply Chain Council (SCC) that among other roles educates the supply council members on its application ([19], pp. 322-344).

The SCOR model integrates the supply chain members by linking the delivery operations of the seller to the sourcing operations of the buyer. This is done in six categories: plan, source, make, deliver, return, and enable:

Plan: this involves planning all the activities involved in demand and supply of products/services (resources, communication, performance, inventory, capital/ assets, transportation, and others).

Source: this comprises sourcing of stocks, make to order, engineer to order, scheduling deliveries, selecting suppliers, and managing incoming inventories.

Make: the production process: make to stock, make to order, engineer to order, and other production networks.

Deliver: it involves order preparation, warehouse, transportation, and distribution of products.

Return: return of purchased materials to suppliers and finished goods from customers and managing the return process.

Enable: the process of establishing, maintaining, and monitoring information, relationships, resources, assets, design, planning, and execution of supply chain.

The SCOR model is for all types of supply chains, but its application identifies more with the characteristics of GSCM.

\section{Supply chain collaboration (SCC)}

Advancing GSCM requires a high level of supplier-customer informationsharing relationship in a form of collaboration and integration. "Collaboration in supply chain is a process through which trading partners can jointly plan key supply chain activities from the delivery of raw materials, through production and delivery of finished products to the end customers. The process encompasses business 
planning, sales forecasting and all operations required to replenish raw materials and finished products" ([5], p. 28).

Supply chain collaboration (SCC) is a relationship between supply chain partners developed over some time. Collaboration commences with open-market negotiations, whereby fewer suppliers cooperate to supply a common customer. Cooperation entails organizations working jointly toward the same goal as in ensuring customer satisfaction. The relationship moves to the next level of coordination through information linkages as in the use of electronic data interchange (EDI). Coordination entails the ability of different organizations sorting out their complexities in a working-together relationship, as supply chain partners do to deliver value to customer. Subsequently, collaboration is achieved when organizations start joint planning and technology sharing (supply chain integration). This indicates that supply chain integration is an enabler of collaboration ([19], pp. 322-344).

Supply chain collaboration is experienced in two types: vertical collaboration and horizontal collaboration ([20], p. 50).

Vertical collaboration is the relationship between suppliers (external), focal organization (internal), and customers (external).

Horizontal collaboration is experienced when the focal organization (internal) collaborates with other organizations and the third-party logistics (3PL) companies (external) for joint transportation.

\section{Supply chain integration (SCI)}

Supply chain integration (SCI) is the alignment and interlinking of business processes. The alignment and interlinkage of the focal organization with the firsttier suppliers and first-tier customers allow the organization to focus its time and resources on managing important process links with other trading partners. These are partners' upstream (suppliers) and downstream (customers) that allow larger and complex supply chain to perform better ([20], p. 48).

\section{Lean and agile supply chain}

The conventional way for the focal organizations or manufacturers is to hold a high level of inbound, internal, and outbound inventories to cover for incidental or unplanned orders. The inbound inventory comprises raw materials from the first-tier suppliers to the manufacturer, internal inventories are the manufactured products and work-in-progress products (unfinished products) at the manufacturer's warehouse, and when the finished products are being shipped to end users (customers), they are inbound inventories ([21], p. 150). These are non-valueadded activities which are avoided in GSCM.

Lean supply chain requires the suppliers to deliver smaller quantities of raw materials more frequently to the manufacturer. As frequent smaller inbound transportation and outbound transportation of finished products add costs, suppliers usually locate warehouses near the manufacturing facilities. In this era of shopping malls, the leading retail chain stores of fast-moving consumer goods (FMCGs) own distribution centers (DCs) at convenient locations to receive supplies from different suppliers to ease distribution to their retail outlets. The DCs are built on national and regional formations depending on the retail outlets' distribution network. Usually, third-party logistics (3PL) companies provide the transportation, although in some isolated situations, retailers substitute 3PL with their own transport. This 
type of logistics arrangement focuses on timeous delivery, to the right location, in right quantities and qualities. Ultimately, this lowers the inventory levels and reduces holding costs ([7], p. 330).

In GSCM, the manufacturers focus on a limited number of suppliers and customers to collaborate in identifying customer requirements. The collaboration process aims to remove waste, reduce costs, and improve quality and customer service. The process renders supply chain "lean" by utilizing limited materials to produce limited inventories and "agile" by responding quickly to unpredictable changes in customer needs. The two terms are coined together to make an emerging word "leagile," a characteristic that distinguishes GSCM with the conventional SCM ([21], p. 329).

\section{Just in time (JIT)}

Just in time (JIT) originated from the Toyota company, Japan, in the 1940s. The Toyota managers such as Taiichi Ohno pursued "Kanban" that involved continuous problem-solving aimed at eliminating waste. However, lean management is more practiced outside Japan as both have similar objectives. JIT enhances supply chain process when suppliers and manufacturers work together or collaborate to enable them to respond more quickly to customer needs. This is done through information-sharing via Internet connectivity, resulting in improved customer service, less inventory holding, and reduced waste. As the supply chain becomes more streamlined and focused in speedy turnaround of smaller quantities, it assumes the characteristics of GSCM. Hence, JIT is crucial for a supply chain to achieve its primary objectives of low cost, high quality, and fast response ([7], p. 249).

\section{Reverse logistics}

Reverse logistics is the process of moving or transporting goods from their final forward destination back to the manufacturer and suppliers for the purpose of creating value or for proper disposal. It involves the processes of sending new or used products "back upstream" for repair, reuse, refurbishing, resale, recycling, scrap, or salvage. In reverse logistics system, items are usually returned to a central location for processing. The processing involves transporting, receiving, testing, inspecting, and sorting for appropriate actions such as repair, refurbish, or resale. Where the product has no value, it is disposed in landfill or other environmentally acceptable processes. The facility and related processes are provided either by the original manufacturer or a third-party logistics (3PL) company. The characteristics of reverse logistics that involves preparing returned products for reuse, recycling, remanufacturing, and proper disposal are identified with GSCM ([6], p. 614).

In reverse logistics, items may be collected from diverse geographical locations, and some of them could be hazardous materials. The hazardous materials would require special handling and disposal. Usually, items collected in reverse logistics go through a tedious process of testing, sorting, grading, and inspecting. Other complexities and challenges experienced are in remanufacturing, reconditioning, and reselling that could be problematic depending on the type of items involved. Thus, green logistics is executed through five stages comprising of suppliers, manufacturers, distribution centers (DCs), customers, and dismantlers or recyclers ([21], p. 47).

However, despite of all these challenges, reverse logistics add value to the triple bottom line of the organization involved. That entails adding value to an 
organization's economic, social, and environmental attributes. This summarizes the three major drivers of reverse logistics as customer service, environmental issues, and economic benefits. The effective role of reverse logistics is demonstrated by the collaboration of the leading retailers of fast-moving consumer goods (FMCGs) and their suppliers as they proactively pursue reverse flows to capture value [22].

\section{Closed-loop supply chains}

The closed-loop supply chains are designed and managed to explicitly consider both forward and reverse flow activities in a supply chain. The combined roles of forward and backward flow of goods in closed-loop supply chains essentially aim at reducing cost and capturing value. Consequently, closed-loop logistics is a crucial component to supply-demand chain management in closed-loop supply chains. The focal organization or manufacturer proactively utilizes them as they add value to the organization ([6], p. 614).

\section{Green purchasing}

The increasing consciousness in recent times about environmental protection has triggered more interest in green supply chain, sustainability, and green initiatives as they are interrelated. Green purchasing is concerned with the purchase of products that emanate from energy efficiency, bio-based and recycled content, non-ozone-depleting substances, green power, and other environmentally friendly products. Green power refers to electricity generated from sources that have limited greenhouse gas emissions such as renewable sources comprising of hydro, solar, and wind, among others ([16], pp. 35-36).

The Institute of Supply Management defined green purchasing as "making environmentally conscious decisions throughout the purchasing process, beginning with product and process design and through product disposal" ([5], p. 74). Green purchasing in supply chain is supposed to address some of the pressing environmental issues such as ozone layer depletion, global warming, and hazardous waste ([12], p. 324).

The selection of green suppliers is guided by global regulations for environmental protection. The rules and regulations address pertinent issues for environmental management from production of products/services to consumption. Wang and Gupta [4] summarized some of the crucial laws and regulations observed by several countries as follows:

1. Waste Electrical and Electronic Equipment (WEEE) Directive of 2003

2. Restriction of Hazardous Substances (ROHS) Directive of 2010

3. Energy-Using Products (EuP) Directive of 2010

4. End-of-Life Vehicle (ELV) Directive

5. Registration, Evaluation, Authorisation and Restriction of Chemicals (REACH)

The conventional SCM focuses on information flows from vendors to the customers, whereas GSCM must, in addition to this, fulfill the four Rs (4Rs) of green 
factor regulations: reduction, redesign, remanufacturing, and reuse. Industries are increasingly creating environmentally friendly products (green products) to satisfy the customer demand. The green products are made with reduced raw materials, using renewable energy and recycling of old products. The reduction of primary resource use, pollution prevention, waste management, and policies governing sustainable products have become the focus of modern industrial societies and environmental guidance. This distinguishes green supply chain management from the traditional supply chain management as it encompasses environmental impacts and material utilization factors in the selection of suppliers ([6], p. 619).

In pursuit of environmental sustainability in logistics, organizations strive to change the transportation modes of their products to overcome the growing pressure and to improve environmental performance. The rail mode of transportation where feasible is preferred over road use, especially in the haulage of heavy loads as organizations strive to reduce carbon footprint of their products.

\section{Conclusion}

The history of supply chain and the crucial role played by Michael Porter in coining in the application of value chain from his book on competitive advantage in 1985 provided the initial building blocks of supply chain management. The GSCM was defined and elaborated to distinguish it from the conventional SCM. Its impacts and implications to environmental management and benefits to organizations and to product/service end users were exhausted. The global concerns of the greenhouse gas emissions leading to the phenomenon of climate change or global warming and that GSCM drives sustainability goal were discussed in detail. The United Nations watchdog body for global climate change and emissions, the UNFCCC, was also expressed. The narrative included the definition and elaboration of sustainable development.

The pursuance of GSCM by the industry utilizing green materials and green production processes and applying green purchasing which are environmentally friendly was stipulated. The drivers of GSCM such as closed-loop supply chains; lean and agile supply chains; functions such as SCC, SCI, and JIT; and SCOR application were examined.

Subsequently, successful implementation of GSCM was found in Pakistan from an empirical study on GSC practices conducted in the manufacturing firms where four variables of GSCM, namely, ecological design of products, green manufacturing, green information systems, and cooperation with customers, were found to significantly improve organizational performance. Another research in the same country on the impact of GSC on manufacturing firms' economic and environmental performance established that green practices impacted on the environmental performance. These examples demonstrate the role of GSCM as an infrastructure that would drive the unfolding 4IR and business sustainability. 


\section{Author details}

Kenneth Mathu

North West University, South Africa

*Address all correspondence to: kenmathu@yahoo.com

\section{IntechOpen}

(C) 2019 The Author(s). Licensee IntechOpen. This chapter is distributed under the terms of the Creative Commons Attribution License (http://creativecommons.org/licenses/ by/3.0), which permits unrestricted use, distribution, and reproduction in any medium, provided the original work is properly cited. (cc) BY 


\section{References}

[1] Oliver RK, Webber MD. Supply chain management: Logistics catches up with strategy. In: Christopher ML, editor. Logistics: The Strategic Issues. London: Chapman \& Hall; 1982. pp. $63-75$

[2] Porter ME. The Competitive Advantage: Creating and Sustaining Superior Performance. New York: Free Press; 1985

[3] Javier-James AM. A new introduction to supply chains and supply chain management: Definition and theories perspective. International Business Research. 2012;5(1):194-205

[4] Wang H-F, Gupta SM. Green Supply Chain Management: Product Life Cycle Approach. New York: McGraw Hill; 2011

[5] American Production and Inventory Control Society (APICS). The Essential Supply Chain Reference. Chicago, IL: APICS Press; 2013

[6] Coyle JJ, Langley CJ, Novack RA, Gibson BJ. Supply Chain Management: A Logistics Perspective. Boston, MA: Cengage Learning; 2017

[7] Wisner JD, Tan K-C, Leong GK. Principles of Supply Chain Management: A Balanced Approach. 4th ed. Boston, MA: Cengage Learning; 2016

[8] Makower J. Inside Walmart's 2025 Sustainability Goals. Transport Weekly; 2016

[9] Mendoza-Fong JR, Garcia-Alcaraz JL, Diaz-Reza JR, Muro JCS, Fernandez JB. The Role of Green and Traditional Suppliers' Attributes on Business Performance. Sustainability Initiatives, Spanish Universities Contribution [Online]. 2017. Available from:
//C:/Users/mathuk/Downloads/ sustainability-09-01520.pdf [Accessed: 26 March 2019]

[10] Khan SAR, Qianli D. Impacts of green supply chain management practices on firm's performance: An empirical study from the perspective of Pakistan. Environmental Science and Pollution Research. 2017;24(20):1682916844. DOI: $10.1007 / \mathrm{s} 11356-017-9172-5$ [Accessed: 24 May 2019]

[11] Khan SAR, Dong Q. The effects of green logistics on economic growth, social and environmental sustainability: An empirical study of developing countries in Asia. Environmental Science and Pollution Research. 2017;24(34):26692-26705. DOI: 10-20944/preprints201901.0104.v1 [Accessed: 24 May 2019]

[12] As JV, du Preez J, Brown L, Smit N. The History of Life \& the Environment: An African Perspective. Cape Town, SA: Pippa Parker; 2012

[13] Wyk V, Llewellyn V. What are green materials and technologies? [Online]. 2014. Available from: https:// researchspace.csir.co.za/dspace/ handle/10204/7853 [Accessed: 28 March 2019]

[14] Omar AM. Energy use and environmental impacts: A general review. Journal of Renewable and Sustainable Energy. 2009;1(5). Available from:https://aip.scitation.org/doi/abs /10.1063/1.3220701?journalCode=rse) [Accessed: 28 March 2019]

[15] United Nations Framework Convention on Climate Change (UNFCCC). Report on the Conference of Parties on its Fifteenth Session Held in Copenhagen [Online]. Denmark; 2009. Available from: https://www. eea.europa.eu/data-and-maps/ 
indicators/atmospheric-greenhousegas-concentrations-10/unfccc-2009 [Accessed: 27 March 2019]

[16] Unruth G. Earth INC.: Using Nature's Rules to Build Sustainable Profits. Boston, MA: Harvard Business Press; 2010

[17] Brundtland GH. United Nations World Commission on Environment and Development (WCED) [Online]. 1987. Available from: https://www. britannica.com/topic/WorldCommission-on-Environment-andDevelopme [Accessed: 27 March 2019]

[18] King M, Lessidrenska T. Transient Caretakers: Making Life on Earth Sustainable. Johannesburg: Pan Macmillan; 2009

[19] Zhou H, Benton WC. Supply chain integration and the SCOR model. Journal of Business Logistics. 2011;32(4):332-344

[20] Mangan J, Lalwani C, Butcher T, Javadpour R. Global Logistics \& Supply Chain Management. West Sussex: John Wiley; 2012

[21] Pienaar WJ, Vogt JJ. Business Logistics Management: A Value Chain Perspective. Cape Town: Oxford University Press; 2012

[22] Akdogan MS, Coskun A. Drivers of reverse logistics: An empirical investigation. ProcediaSocial and Behavioral Sciences. 2012;58:1640-1649. Available from: https://www.researchgate.net/ publication/271638407_Drivers_of_ Reverse_Logistics_Activities_An_ Empirical_Investigation [Accessed: 28 March 2019] 

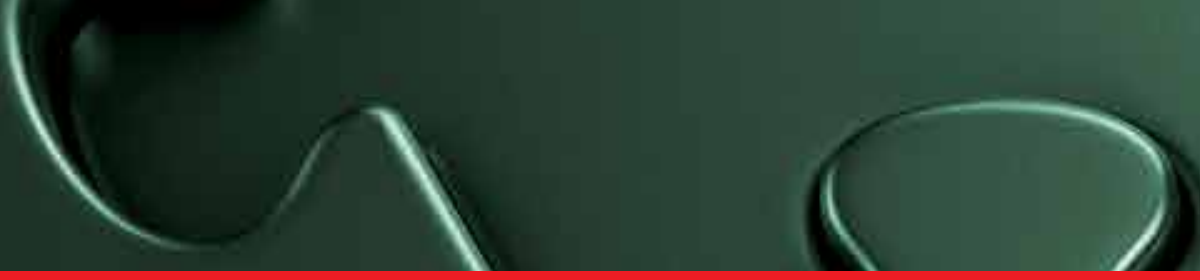

\section{Edited by Syed Abdul Rehman Khan}

We look at green supply chain management from the vantage point of the triple bottom line: environmental, economic, and social. There are many sustainability decisions that can be made on which we have an incredible impact. Usually, managers have the opportunity to make decisions in five areas of the supply chain: plan, source, make, deliver, and return.

Nowadays, consumers care more about where and how the products are produced and delivered, what they are made of, and who made them. Regulatory bodies are continuously creating pressure on firms to adopt eco-friendly practices in their businesses for better environmental sustainability. As a result, firms have just two choices: to adopt green and/or eco-friendly practices in their supply chain operations to fulfill their customers' and regulatory bodies' requirement or not to adopt green practices and lose their business position and potential customers. 